University of South Florida

DIGITAL COMMONS

Digital Commons @ University of

@ UNIVERSITY OF SOUTH FLORIDA

South Florida

Marine Science Faculty Publications

College of Marine Science

2003

\title{
Submarine Strombolian Eruptions on the Gorda Mid-Ocean Ridge
}

David A. Clague

Monterey Bay Aquarium Research Institute

Alicé S. Davis

Monterey Bay Aquarium Research Institute

Jacqueline E. Dixon

University of Miami, jdixon@usf.edu

Follow this and additional works at: https://digitalcommons.usf.edu/msc_facpub

Part of the Life Sciences Commons

\section{Scholar Commons Citation}

Clague, David A.; Davis, Alicé S.; and Dixon, Jacqueline E., "Submarine Strombolian Eruptions on the Gorda Mid-Ocean Ridge" (2003). Marine Science Faculty Publications. 1313.

https://digitalcommons.usf.edu/msc_facpub/1313

This Book Chapter is brought to you for free and open access by the College of Marine Science at Digital Commons @ University of South Florida. It has been accepted for inclusion in Marine Science Faculty Publications by an authorized administrator of Digital Commons @ University of South Florida. For more information, please contact digitalcommons@usf.edu. 


\title{
Submarine Strombolian Eruptions on the Gorda Mid-Ocean Ridge
}

\author{
David A. Clague and Alicé S. Davis \\ Monterey Bay Aquarium Research Institute, Moss Landing, California
}

Jacqueline E. Dixon

\begin{abstract}
Rosenstiel School of Marine and Atmospheric Science, University of Miami, Miami, Florida
Compositionally variable limu o Pele occurs in widely distributed sediments collected during ROV Tiburon dives along the Gorda Ridge axis. The fragments formed deeper than the critical depth of seawater and are unlikely to be formed by supercritical expansion of seawater upon heating in contact with hot lava. Discharge of $\mathrm{CO}_{2}$ through erupting lava is the most likely way to make such bubbles at $>298$ bars pressure. The distribution and composition of limu o Pele fragments indicate that low-energy strombolian activity is a common, although minor, component of eruptions along mid-ocean ridges. Combined dissolved and exsolved volatile contents of N-MORB from the Gorda Ridge with 12.8-15.6\% spherical vesicles are about $0.78 \% \mathrm{CO}_{2}$ and $0.18 \mathrm{wt} \% \mathrm{H}_{2} \mathrm{O}$ and exceed estimates of primary $\mathrm{CO}_{2}$ of only 0.07 to $0.095 \mathrm{wt} \%$ calculated from whole rock $\mathrm{Nb}$ concentrations. This discrepancy suggests that the magmas accumulated an exsolved volatile phase prior to eruption. The evidence that a separated volatile phase drives strombolian eruptions on the seafloor also implies that volatile bubbles coalesce during storage or transport to the surface. The combination of large bubbles in otherwise dense magma suggests nearly complete coalescence of small bubbles and is most consistent with accumulation of the exsolved volatile phase, most likely near the tops of crustal magma chambers, prior to upward transport in shallow conduits to the eruptive vents on the seafloor. A portion of this $\mathrm{CO}_{2}$-rich separated fluid phase is released in brief bursts during eruptions where it becomes part of event plumes.
\end{abstract}

\section{INTRODUCTION}

Abundant observations and sampling along mid-ocean ridges [e.g., Ballard et al., 1979; Perfit and Chadwick, 1998; Batiza and White, 2000] have led to the widely

Explosive Subaqueous Volcanism

Geophysical Monograph 140

Copyright 2003 by the American Geophysical Union

10.1029/140GM07 accepted view that submarine basaltic eruptions are effusive. These eruptions produce pillow, lobate, and sheet flows [e.g., Perfit and Chadwick, 1998], with the flow type mainly determined by effusion rate [e.g., Griffiths and Fink, 1992; Gregg and Fink, 1995]. Associated basaltic volcaniclastic deposits are rare, but occur in a variety of tectonic settings and at a range of depths.

Many of these deep-sea volcaniclastic deposits contain common to rare sideromelane bubble-wall fragments in addition to the usually more abundant dense angular 
sideromelane fragments. Bubble-wall fragments, named limu o Pele or Pele's seaweed, were first described from Kilauea's ongoing eruption [Hon et al., 1988] where they form as lava entering the ocean produces lava bubbles due to incorporation of seawater into the lava stream and expansion to steam [Mattox and Mangan, 1997]. This limu o Pele formed at sealevel in a littoral environment, where the volume change as water expands to steam is large. The expansion of seawater during boiling is greatly diminished with increasing pressure, however, making formation of limu o Pele by this mechanism less likely as eruption depth increases. Calculations of the specific volume of the combined vapor-liquid-solid phases generated during boiling [see Figure 9 in Clague et al., 2000a] indicated that seawater undergoes up to about 20 times volume expansion at roughly $2 \mathrm{~km}$ depth, still adequate for limu o Pele formation. However, at supercritical conditions (greater than $407^{\circ} \mathrm{C}$ and 298 bars or $\sim 2936 \mathrm{~m}$ depth [Bischoff and Rosenbauer, 1988]), the volume expansion from heating seawater is limited to about a factor of four and is not instantaneous, since no phase change occurs. In order to form limu o Pele, bubbles must grow at rates that exceed the cooling rate of the glass, since the wall must remain plastic to continue to stretch. Expansion of seawater under supercritical conditions is unlikely to be rapid enough to form limu o Pele, as recently proposed for samples from subcritical depths [e.g., Clague et al., 2000; Maicher and White, 2001].

Volcaniclastic deposits containing limu o Pele fragments have been documented around Hawaii, on a near ridge seamount off the EPR, on the Azores Platform section of the MAR, and on the Sumisu rift. None have been previously described from a normal mid-ocean ridge. Existing occurrences of limu o Pele are described in more detail below.

Tholeiitic limu o Pele fragments have been recovered from Kiluaea's Puna Ridge in sediment at $>5400 \mathrm{~m}$ at the base of Puna Ridge, although their dissolved volatile contents indicate they erupted at about $2000 \mathrm{~m}$ depth [Clague et al., 1995], and from about $2200 \mathrm{~m}$ depth [Clague et al., 2000a]. These are similar to littoral limu o Pele produced from the ongoing eruption of Kilauea, but less vesicular. Limu o Pele was also found in unconsolidated sand deposits on Loihi Seamount between 1150-1950 m depth. The Loihi limu o Pele fragments are mainly dense tholeiitic basalt $(81 \%)$, although some are transitional basalt $(12 \%)$ or alkalic basalt (7\%) [Clague et al., 2000a]. The curvature of the fragments suggests that the average bubble diameter of tholeiitic limu o Pele from Loihi is $5.9 \mathrm{~cm}$.

Morphologically similar limu o Pele fragments of MORB and hawaiite composition were described from Seamount 6 near the East Pacific Rise from 1600-2000 m depth
[Maicher and White, 2001]. These fragments formed the basis for a detailed model of limu o Pele formation in the deep sea [Maicher and White, 2001] that also relied entirely on the expansion of seawater as it boils [see Figure 9 in Clague et al., 2000a, and Figure 5 in Maicher and White, 2001] to produce thin-walled lava bubbles. Maicher and White [2001] proposed that seawater is incorporated into thin, fluid, rapidly advancing lava flows that covered watersaturated sediment.

Volcaniclastic deposits of enriched-MORB occur as deep as $1700 \mathrm{~m}$ at $37^{\circ} 50^{\prime} \mathrm{N}, 31^{\circ} 32^{\prime} \mathrm{W}$ on the Mid-Atlantic Ridge [Fouquet et al., 1998; Eissen et al., this volume]. The fragments in these deposits include scoria and pumice interpreted as evidence that exsolution of magmatic volatiles played a large role in magma fragmentation. The increased surface area of the melt in contact with seawater apparently then led to hydrovolcanic explosions and the formation of small plate-like shards and abundant lithic and broken crystal fragments. Based on this evidence, Fouquet et al. [1998] argue that the volcaniclastic deposits formed due to submarine explosions involving a combination of magmatic volatile exsolution and bulk/surface steam explosivity, probably accompanied by thermal-contraction fragmentation.

Scoriaceous back-arc basin basaltic breccia occurs at about $1800 \mathrm{~m}$ in the Sumisu Basin [Gill et al., 1990]. The glass contains about $1.3 \% \mathrm{H}_{2} \mathrm{O}$ after vesiculation, which suggests that high initial magmatic $\mathrm{H}_{2} \mathrm{O}$ contributed to the explosivity. Gill et al. [1990] also argued, based on textural and magnetic data, that the breccia was assembled while hot, despite accumulation in deep water.

Strongly alkalic North Arch lavas, ranging from alkalic basalt to nephelinite, formed volcaniclastic deposits containing vesicular angular and rounded glass fragments, spherical glass droplets [Clague et al., 1990], and thin curved glass fragments interpreted as limu o Pele [Clague et al., 2002] during eruptions at $4160 \mathrm{~m}$, well below the critical depth for seawater. Unfortunately, limu o Pele fragments in these samples were mostly altered to palagonite. These fragment shapes were interpreted to form by fragmentation during eruption, most probably by magmatic volatile exsolution. Several additional samples from about $4320 \mathrm{~m}$ collected by the Shinkai 6500 submersible in August 2002 (dive S704) contain unaltered angular and limu o Pele fragments up to several $\mathrm{mm}$ across. The limu o Pele fragments, compared to those from Loihi Seamount [Clague et al., 2000a], include some small vesicles and the fragments tend to be thicker and less regularly curved.

In summary, volcaniclastic deposits from the MidAtlantic Ridge [Fouquet et al., 1998; Eissen et al., this volume], the Sumisu Backarc Basin [Gill et al., 1990], and the North Arch volcanic field [Clague et al., 1990, 2002] were 
interpreted as pyroclastic deposits with fragmentation driven by exsolution of magmatic $\mathrm{H}_{2} \mathrm{O}$ in the case of the Sumisu basin and magmatic $\mathrm{CO}_{2}$ in the other cases. On the other hand, those from Puna Ridge [Clague et al., 2000a], Loihi Seamount [Clague et al., 2000a], and Seamount 6 [Maicher and White, 2001] were interpreted as hydrovolcanic deposits with fragmentation driven by steam explosivity.

In this paper, we describe volcaniclastic deposits from a number of locations along the Gorda Mid-Ocean Ridge that contain limu o Pele that are inferred to have formed deeper than the critical depth for seawater. We present evidence that submarine limu o Pele is of pyroclastic, rather than hydrovolcanic, origin. We then argue that submarine limu o Pele and angular sideromelane fragments form during mild strombolian-like eruptions driven by a separated magmatic volatile phase, dominated by $\mathrm{CO}_{2}$ along mid-ocean ridges. We conclude with an evaluation of volatile budgets for normal MORB and some speculation about a magmatic component to event plumes.

\section{VOLCANICLASTIC MORB FROM GORDA RIDGE}

\subsection{Geologic Setting and Ridge Morphology}

The Gorda Ridge is a $300-\mathrm{km}$-long mid-ocean ridge located 250 to $350 \mathrm{~km}$ west of the northern CaliforniaOregon margin (Figure 1). The ridge is similar in structure to the slow-spreading Mid-Atlantic Ridge and is characterized by a deep axial valley [Clague and Holmes, 1987] that is divided into 5 offset segments named, from south to north, the Escanaba, Phoenix, Central, Jackson, and Northern segments [Chadwick et al., 1998]. The ridge is bounded on the north and south by the Blanco and Mendocino Fracture Zones, respectively. The neovolcanic zone of the northern four segments consists dominantly of pillow flows with variable, but thin sediment cover [e.g., Clague and Rona, 1989]. The sedimentation rate along Gorda Ridge is relatively high, roughly $5-14 \mathrm{~cm} / \mathrm{ky}$ [Karlin and Zierenberg, 1994]. In places, the floor of the neovolcanic zone is broken by faults and fissures, usually oriented parallel to the ridge axis. The neovolcanic zone along Gorda Ridge ranges from 2867 to $3975 \mathrm{~m}$ deep, with only 5 volcanic cones in the entire neovolcanic zone shallower than $2936 \mathrm{~m}$. The Escanaba segment is filled with turbidite sediments [e.g., Zuffa et al., 2000] and the neovolcanic zone is characterized by sills intruded into the sediment [Morton et al., 1994, Normark and Serra, 2001]. The only lava flows are an extensive one at the NESCA hydrothermal site near $41^{\circ} \mathrm{N}, 127^{\circ} 30^{\prime} \mathrm{W}$ and a smaller one at the SESCA hydrothermal site at $40^{\circ} 47^{\prime} \mathrm{N}, 127^{\circ} 31^{\prime} \mathrm{W}$ [Ross and Zierenberg, 1994; Davis et al., 1994]. The northern end of

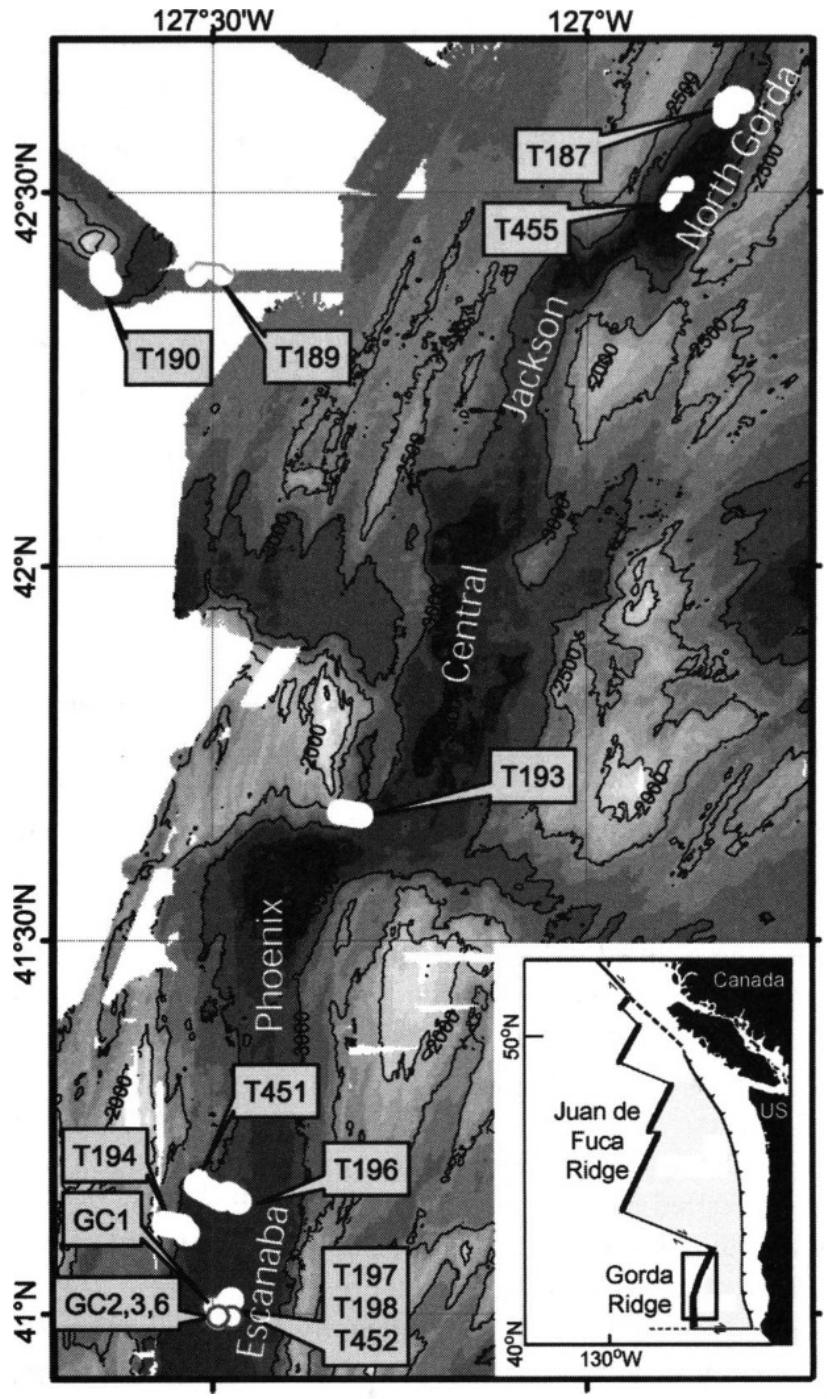

Figure 1. Location map showing Tiburon ROV dive locations on Gorda Ridge. Segments of Gorda Ridge axis are labeled. The vesicular MORB samples are from dive T196 and the limu o Pele fragments were recovered in push-cores and sediment scoops during dives T187, T189, T190, T193, T194, T196, T197, T198 in 2000 and during T451, 452, 453, and 455 in 2002 and two gravity cores collected near dives T197 and T198 in 2000 .

the Escanaba segment has a group of nearly circular volcanic cones that project above the sediment fill.

\subsection{Volcaniclastic Deposits}

Volcaniclastic deposits are briefly described from about $3100 \mathrm{~m}$ depth at the 1996 eruption site by Chadwick et al. [1998]. A bottom photograph (their Figure 3b) shows volcaniclastic black sand on gray talus deposits. They attribute the fine clastic material to fragmentation as pillow lava cas- 

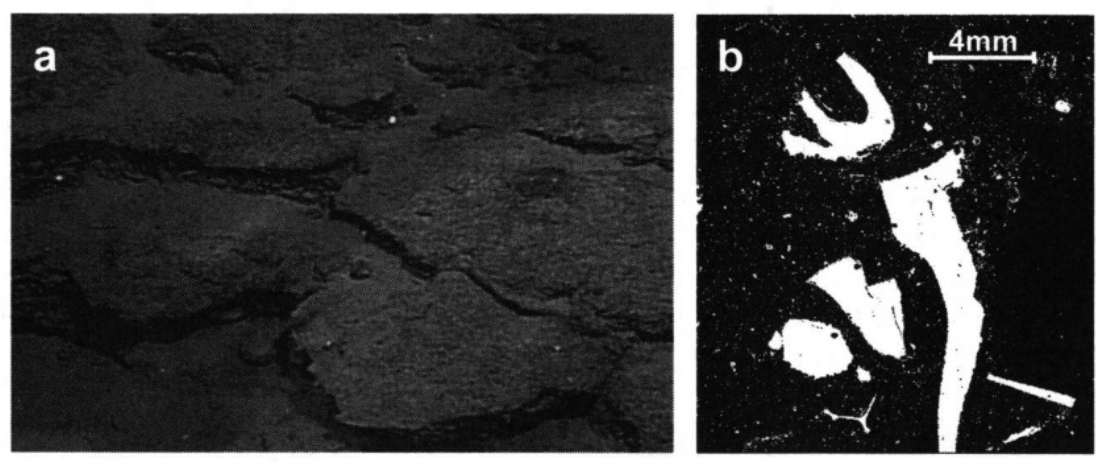

Figure 2. a) Bottom photograph showing fine-grained volcaniclastic deposit at $2883 \mathrm{~m}$ depth observed on Tiburon dive T190 at top of ridge-parallel fault scarp west of Gorda Ridge axis, field of view is about $1 \mathrm{~m}$ wide, b) backscattered electron photomicrograph showing dense fluidal shaped glass fragments in fine-grained matrix consisting of glass fragments to submicron sizes (bright specs).

caded over a fault scarp. The volcaniclastic deposit was not sampled.

We observed and recovered volcaniclastic deposits during two dive programs using MBARI's R/V Western Flyer and remotely operated vehicle (ROV) Tiburon in August 2000 and July 2002. During dive T190 in 2000, we observed a thin fine-grained volcaniclastic deposit (Figure 2a) at 2883 $\mathrm{m}$ depth near the top of a ridge-parallel fault scarp west of the ridge axis. The recovered sample contains dense sandto-silt sized angular glass fragments and abundant dense, sand-to-silt sized, limu o Pele in a matrix of finely (to submicron sizes) comminuted glass (Figure $2 b$ ). The ash may have erupted from the easternmost of the President Jackson Seamounts [Davis and Clague, 2000], located to the west. The summit of this seamount presently reaches $1723 \mathrm{~m}$ depth, but was probably significantly shallower when the volcano was active and located nearer the spreading center. Due to the uncertainty in the depth of formation of this deposit, we will not discuss it further.

The remaining samples of volcaniclastic materials, and those we will focus on, were collected within the neovolcanic zone along the Gorda Ridge using push-cores and sediment scoops to recover fragments embedded in hemipelagic sediment consisting mainly of mud. At none of the locations were volcaniclastic deposits observed prior to sampling. Sampling sites were selected where sediment cover was thick enough to insert push-cores. Glass fragments were nonetheless recovered in all the samples, except those push-cores collected at the SESCA site in the Escanaba segment. Most of the push-cores yielded only a tiny fraction (a few percent) of glass.

Limu o Pele fragments were recovered in 26 push-cores and sediment scoops during 8 dives using the MBARI ROV Tiburon in August 2000, as well as in 2 gravity cores deployed from the R/V Western Flyer. Eleven push-cores from 3 additional dives in 2002 also recovered angular sideromelane and limu o Pele fragments. The sites where limu o Pele fragments were recovered are shown in Figure 1 and their distribution as a function of depth is shown in Figure 3. The deepest site is at $3853 \mathrm{~m}$ at the southern end of the neovolcanic zone on the Northern segment and the shallowest is off-axis at $2595 \mathrm{~m}$ on the west flank of the Escanaba segment.

\subsection{Morphology of Fragments}

The recovered volcanic fragments are almost entirely unaltered sideromelane glass as dense angular fragments

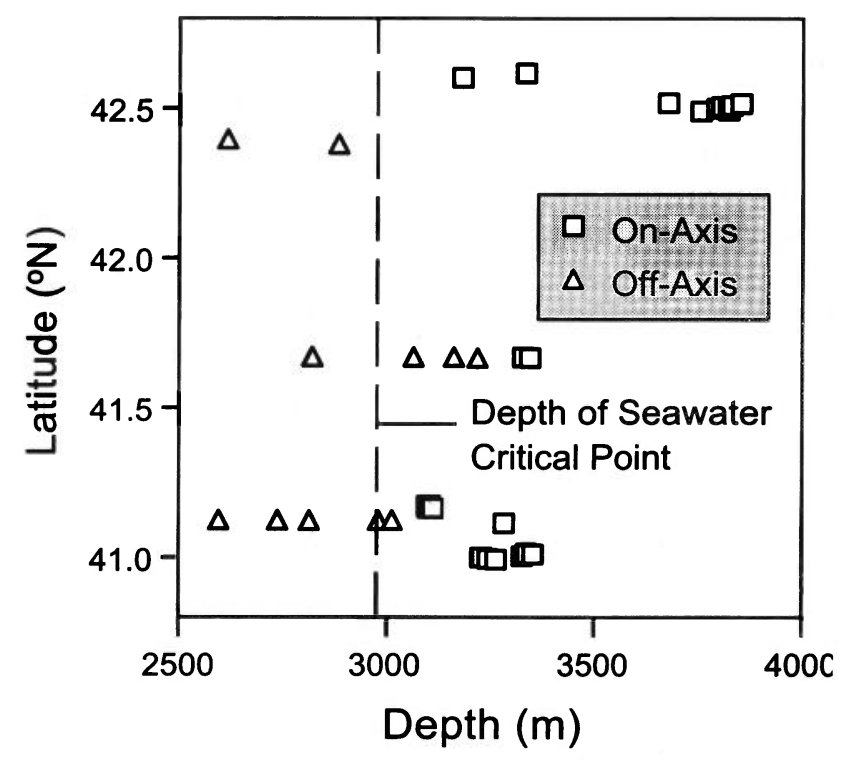

Figure 3. Latitude vs depth of sediment samples from Gorda Ridge that included limu o pele fragments. The samples are divided into axial and off-axis samples. 
(Figure 4a) or dense limu o Pele fragments (Figure 4b). Samples from some sites contain plagioclase crystals and glass fragments from other sites have thin white or light tan alteration products or deposits on all sides of the fragments. In most samples, most glass fragments are angular or have concoidal fractures on flat sheets or elongate needles of glass. Most limu o Pele fragments are thin, dense, slightly curved sheets that are smooth on both sides (Figure $4 \mathrm{~b}$ ) or striated on one side (Figure 5b). The thickness is highly variable from nearly colorless transparent sheets a few microns thick to dark brown glass several tens of microns thick (color intensity in Figure $4 \mathrm{~b}$ is due to variable glass thickness). The striated fragments also have variable thickness, but in elongate patterns. These same fragments com-

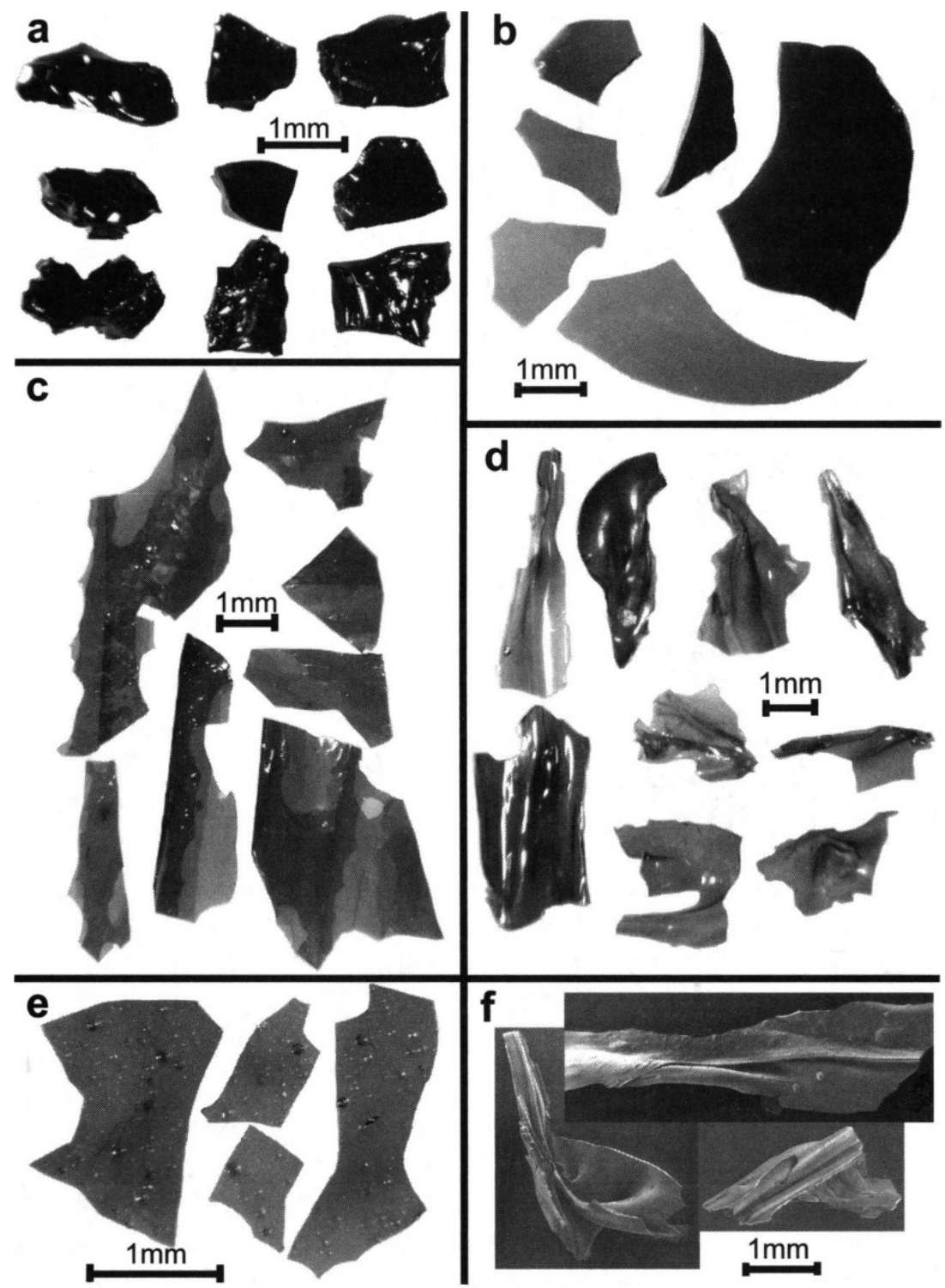

Figure 4. Photomicrographs of samples from Tiburon ROV dives on Gorda Ridge in 2000 and 2002. a) dense angular fragments. Pushcore T452-PC67; b) slightly curved limu o Pele sheets that are smooth on both sides. Variable color intensity is due to variable glass thickness. Pushcore T452-PC67; c) limu o Pele fragments that consist of two or even three thin sheets of glass that are tack-welded together. Pushcore T452-PC67; d) limu o Pele fragments that are folded on themselves and tack-welded. Pushcore T196-PC47; e) rare limu o Pele fragments with abundant small vesicles. Pushcore T452-PC67; f) scanning electron microscope images of folded, tack-welded limu o Pele fragments. Left fragment from T193-PC41, top from T196-PC47, and lower right from T193-PC43. 
monly contain stretched bubbles with pointed ends (upper right in Figure 5b). Some fragments have a mottled appearance (Figure 5a) due to variable thickness and others contain abundant small vesicles (Figure 4e). The larger of the vesicles in the fragments are broken open, usually on the concave inner wall of the fragment. Other fragments consist of two or even three thin sheets of glass that are tack-weld- ed together (Figure 4c). The layers in these fragments are welded together over most of the surface. Many limu o Pele fragments thicken to one edge (Figure 5d) while others are folded on themselves and tack-welded (Figures $4 \mathrm{~d}$ and $4 \mathrm{f}$ ). There are also small fragments of fluidal clasts, which commonly are elongate stretched and twisted glass fragments (Figure 5c). Fluidal clasts range from striated fragments

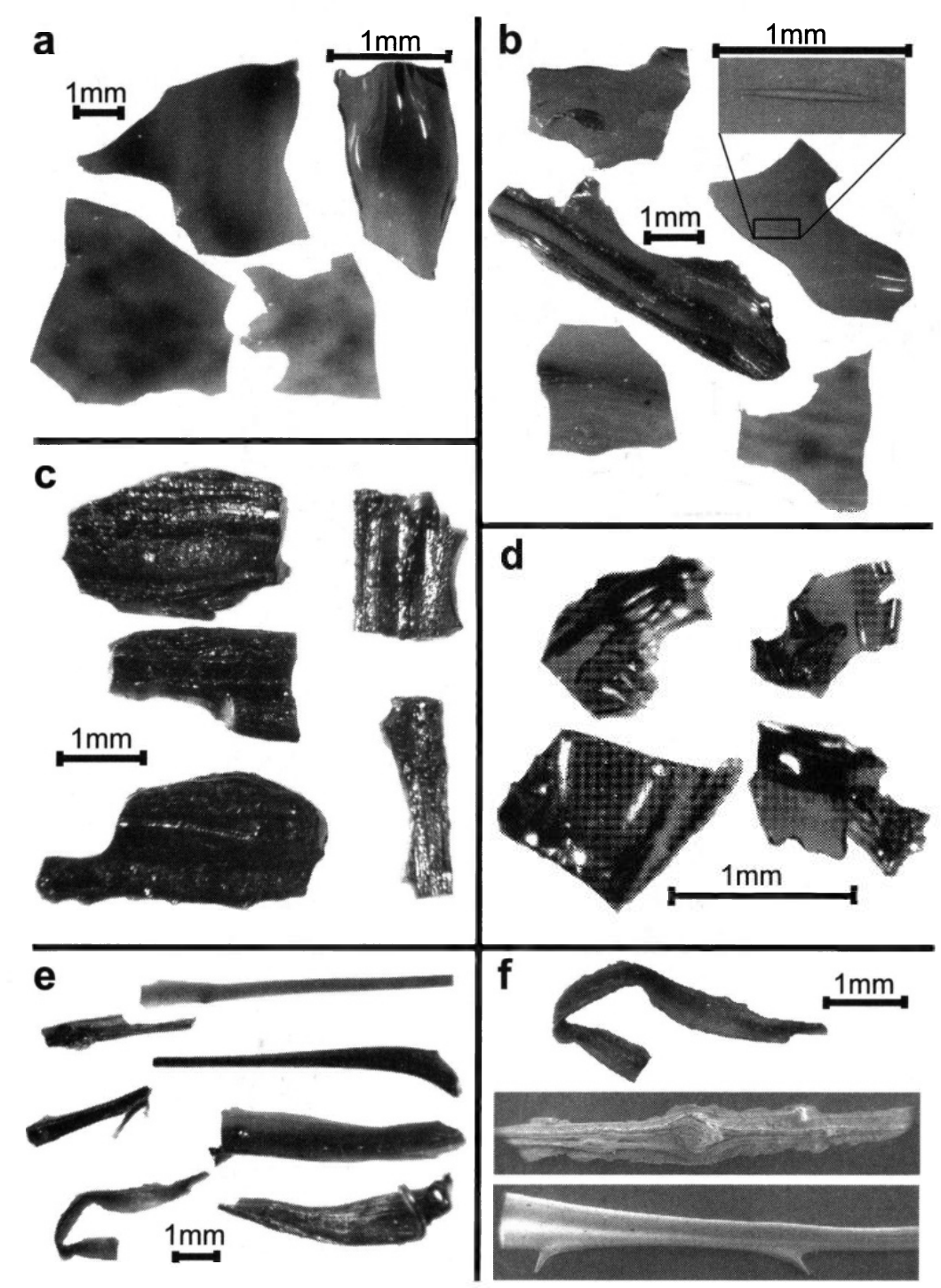

Figure 5. Photomicrographs of samples from Tiburon ROV dives on Gorda Ridge in 2000 and 2002. a) three left fragments are mottled limu o Pele, pushcore T452-PC67; upper right fragment has variable thickness, pushcore T452-PC67; b) limu o Pele fragments, pushcore T193-PC47. Upper left fragment has spatter bleb agglutinated to surface, center left is gradational to spatter, other three fragments are striated. Close-up shows that striation in some fragments is due to presence of elongate stretched vesicles; c) small spatter fragments, pushcore T452-PC67, d) limu o Pele that thicken to one edge, pushcore T455-PC57; e) twisted and elongate glass fragments that resemble Pele's hair when extremely elongate, pushcore T194-PC46; f) top image is ribbon spatter enlarged from e); middle is scanning electron microscope image of stretched spatter, T196-PC47; and bottom is scanning electron microscope image of Pele's hair with barbs, T194-PC46. 
(left center fragment in Figure 5b) to small stretched rods of glass that resemble Pele's hair when extremely elongate (Figures $5 \mathrm{e}$ and $5 \mathrm{f}$ ). Some of the clasts have a ribbon-like morphology (upper fragment in Figure 5f). There are also rare fragments of limu o Pele with small bits of ribbon-like glass agglutinated to their surfaces (upper left fragment in Figure $5 b$ ).

Most limu o Pele fragments are morphologically similar to those from Loihi Seamount described by Clague et al. [2000] in having few vesicles or crystals in the glass. One difference is that the curved fragments from Gorda Ridge are rarely regular enough to allow measurements of the initial diameter of the entire lava bubble. The few whose curvature can be determined appear to be from bubbles only a few centimeters in diameter compared to the average $5.9 \mathrm{~cm}$ diameter of the measured Loihi bubbles, but similar in size to those reported from Seamount 6 [Maicher and White, 2001]. Some rare fragments appear almost flat and represent fragments derived from larger diameter glass bubbles.

\subsection{Chemical Compositions of the Volcaniclastic Fragments}

We analyzed 241 limu o Pele fragments from the 28 sediment samples recovered in 2000 . The fragments range from enriched-MORB to depleted-MORB (Figure 6a). Many have similar compositions to pillow rind glasses from the same dives (Figure 6b), but a number of compositions, including the most enriched-MORB from dive T194, was not sampled as a lava flow. We have also compared the compositional variation of dense angular glass fragments recovered in the same sediment samples and find that there is strong overlap in compositional groups with the limu o Pele fragments (Figure 6c).

Samples from dives T197 and T198 from the NESCA hydrothermal site [Morton et al., 1994], have overlapping glass compositions for pillow rind glasses, dense angular glass fragments and limu o Pele fragments, although the limu o Pele and dense angular fragments extend to somewhat lower $\mathrm{MgO}$ than do the sampled pillow rind glasses (6.5\% MgO compared to 6.7\%). No angular or limu o Pele fragments were recovered at SESCA (dive T199) or an area south of SESCA (dive T200) that are dominated by shallow intrusive sills, rather than surface lava flows. Fragments formed during eruption of the SESCA lava flow may simply

Figure 6. $\mathrm{K}_{2} \mathrm{O}$ versus $\mathrm{MgO}$ plots for Gorda Ridge glass samples of a) limu o Pele fragments recovered from sediment samples, b) all pillow rinds collected on same dives, and c) angular fragments recovered from same sediment samples as in a).

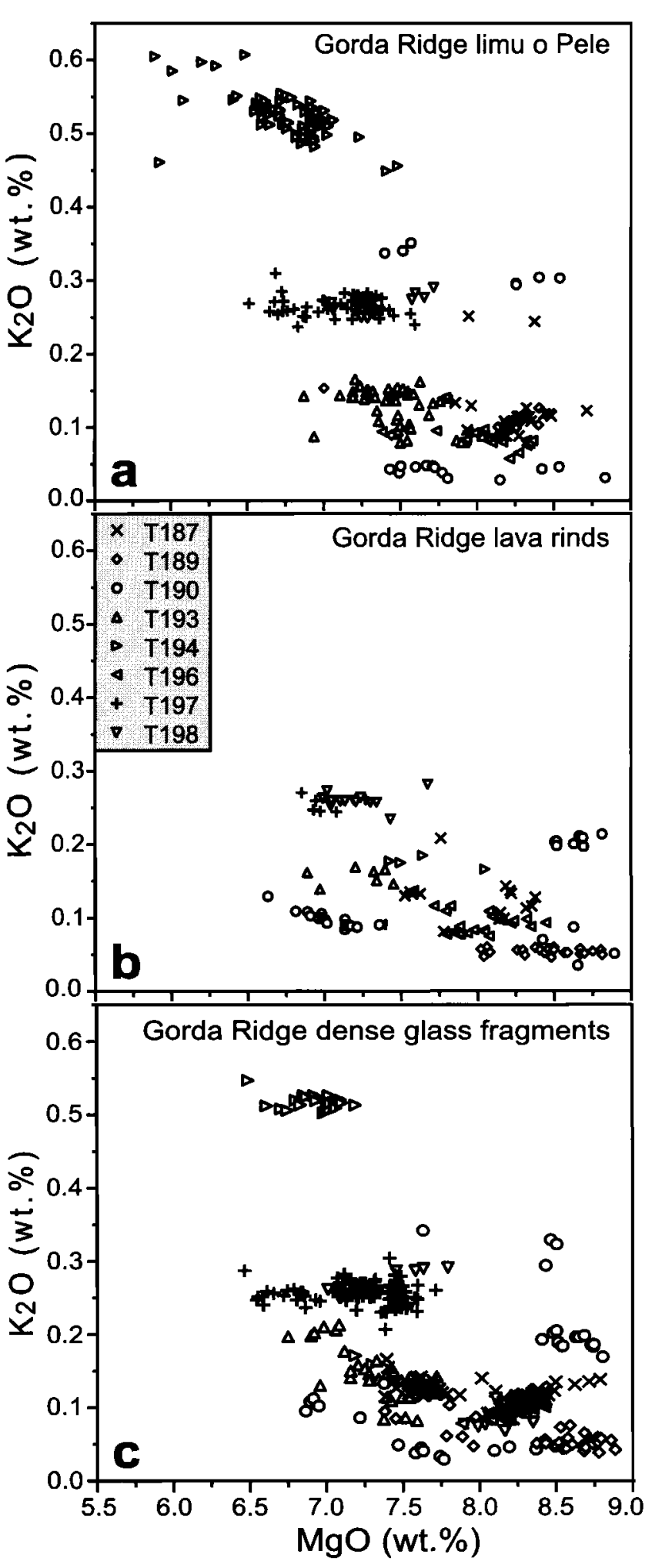


be too old and covered by sediment too thick to be sampled using $25-\mathrm{cm}$ long push-cores.

\subsection{Formation of limu o Pele on the Gorda Ridge}

Most of the limu o Pele fragments from the Gorda Ridge was collected at depths greater than the critical point of seawater (Figure 3 ). If the limu o Pele recovered along the Gorda Ridge from supercritical depths actually formed at those depths, then another mechanism is required to explain formation of limu o Pele. Could it have been produced nearby at depths shallower than the critical point of seawater, transported in the water column, and deposited at the sites where we collected the samples? The short $21-\mathrm{cm}$ cores collected, coupled with regional sedimentation rates of 5-14 $\mathrm{cm} / \mathrm{ka}$ [Karlin and Zierenberg, 1994], suggest that the cores sampled sediment accumulated during the last 2 to $4 \mathrm{k}$. $\mathrm{y}$. Age estimates based on ${ }^{238 \mathrm{U}-230} \mathrm{Th}$ disequilibria [Goldstein et al., 1992] indicate that such young eruptions occur within the neovolcanic zone along a narrow band in the center of the axial valley. The entire Gorda Ridge has been mapped by both Seabeam [Chadwick et al., 1998] and high-resolution Simrad EM300 [MBARI Mapping Team, 2001] swath systems. These maps show that the only locations along the entire Gorda Ridge where the neovolcanic zone is shallower than $2936 \mathrm{~m}$ are the summits of 5 volcanic cones. One is located at the northern end of the Escanaba segment (summit at $2925 \mathrm{~m}$ ), 3 are located near the center of the Phoenix segment (summits at 2867,2903, and $2930 \mathrm{~m}$ ), and 1 is located in the center of the Northern segment (summit at $2883 \mathrm{~m}$ ). Only the summits of these cones rise $11,69,33,6$, and $53 \mathrm{~m}$ above the $2936 \mathrm{~m}$ depth of the critical point of seawater in this area and subcritical conditions for seawater boiling could have occurred only during the final growth of these 5 cones.

If seawater boiling with generation of a vapor phase is responsible for the limu o Pele collected along the Gorda Ridge, then all limu o Pele formed near the summits of these 5 cones and was redistributed along the ridge. The limu o Pele samples recovered at the southern end of the Northern segment are located $33 \mathrm{~km}$ from the only shallow cone in the northern half of the Gorda Ridge. The limu o Pele collected at NESCA in the Escanaba segment is located about $23 \mathrm{~km}$ from the nearest shallow cone. These are long distances to transport dense angular fragments as large as several $\mathrm{mm}$. The wide compositional range of limu o Pele (Figure 6a) also make it unlikely that all were erupted from these five cones, particularly since our sampling of some of these and other cones along the axis shows that each cone consists of lava with only a small compositional range. Finally, the large lava flow at NESCA is compositionally unique for the entire Gorda Ridge [Davis and Clague, 1987, 1990; Davis et al., 1994, 1998; Rubin et al., 1998]. The compositional match of the bubble-wall and angular glass fragments to the flow suggests that the bubble-wall fragments were locally derived. The vent(s) for the NESCA flow are at depths no shallower than $3250 \mathrm{~m}$, well below the critical depth of seawater. These observations demonstrate that most, if not all, limu o Pele from the Gorda Ridge was not only recovered from, but formed at, depths greater than the critical depth of seawater.

If rapid seawater expansion cannot form limu o Pele at supercritical depths, the most likely alternative is that the lava bubbles formed by release of magmatic volatiles exsolved from the magma. Therefore, we propose that limu o Pele at supercritical conditions probably forms during pyroclastic eruptions. The similarity of the fragment morphology and vesicularity of limu o Pele from the Gorda Ridge, where most formed at depths exceeding the critical point of seawater, to that from Loihi Seamount and Puna Ridge [Clague et al., 2000], and Seamount 6 along the East Pacific Rise [Maicher and White, 2001], suggests a common mode of formation. Limu o Pele from all these submarine sites differs from the littoral limu o Pele from Kilauea because the fragments are dense rather than highly vesicular glass and the individual fragments tend to be more uniform in thickness. We propose that limu o Pele at all these submarine sites formed during pyroclastic eruptions, regardless of depth, in which exsolved magmatic volatiles disrupted and fragmented magma at vents.

\subsection{Eruption Style}

What style were these eruptions? Since the eruptions are characterized by release of exsolved magmatic volatiles, they could be either strombolian or hawaiian, or an undescribed style. Strombolian eruptions are characterized by gas and pyroclast discharge in energetic bursts [Blackburn et al., 1976; Ripepe et al., 1993; Vergniolle and Jaupart, 1986]. Models of strombolian eruption dynamics fall generally into two classes [Vergniolle and Mangan, 2000], those based on collapse of a foam layer in a magma reservoir [Vergniolle and Jaupart, 1990] and bubble coalescence through differential rise speeds of melt and bubbles in the conduit [Parfitt and Wilson, 1995]. Both models produce large volatile bubbles in the magma prior to eruption; these bubbles migrate upward in the conduit as a slug flow. Hawaiian fountains, on the other hand, are produced when many small bubbles nucleate and expand in the rising melt, accelerate and disrupt the magma in the conduit, and produce a continuous overshoot of the vent [Head and Wilson, 1987, 1989]. 
Head and Wilson [2003] recently reviewed the theory, landforms, and deposits produced by strombolian and hawaiian eruptions in the submarine environment. Head and Wilson [2003] note that deep submarine hawaiian fountains would require such large volatile inventories that basaltic magmas, except for a few highly alkalic and volatile-rich magma types, simply do not contain sufficient volatiles to form such eruptions. The required volatile inventories rise dramatically with increasing pressure, so that a magma at depths as great as $3850 \mathrm{~m}$ (depth of the deepest limu o Pele from Gorda Ridge) would have to contain somewhat greater than $13 \mathrm{wt} \% \mathrm{CO}_{2}$ (extrapolated from $3500 \mathrm{~m}$ values in their Table 1). Such volatile requirements effectively eliminate the possibility of hawaiian eruptions at these depths. In addition, if the eruptions were hawaiian in character, the angular and the limu o Pele fragments should be highly vesicular and the deposits would most likely be much larger than the observed limu o Pele-bearing deposits. This leaves strombolian as the most likely eruption style to produce limu o Pele in the submarine environment. The eruptions that we propose form limu o Pele are not identical to subaerial strombolian eruptions, but vigorous disruption of the magma surface by slugs of coalesced bubbles are critical in producing pyroclasts in both. We have called these eruptions strombolian, mainly due to this similarity in mechanism. Do the particle types produced tell us anything about how the volatiles accumulated or why subaerial strombolian activity does not produce limu o Pele?

Submarine limu o Pele consists almost entirely of dense glass, as do the associated angular glass fragments. Some exceptions occur, such as the rare fragments described above from Gorda Ridge (Figure 4e), at Loihi Seamount where rare limu o Pele of alkalic basalt composition is moderately vesicular [Clague et al., 2000], and among the strongly alkalic North Arch cones described in the introduc- tion. All the exceptions are only mildly vesicular. The large volatile bubbles that form the submarine sideromelane bubbles (that shatter to form the limu o Pele fragments) therefore discharge through magma that is usually nearly free of small vesicles. As these volatile bubbles rise to the surface of the magma at or near the vent, they create low lava fountains that produce angular glass fragments. In some cases, vigorous bubbling stretches the surface into thin sideromelane bubbles that fragment to become limu o Pele. The absence of small volatile bubbles, but presence of large volatile bubbles, suggests that small bubbles either did not form or have coalesced into large bubbles during magma storage or ascent.

In subaerial strombolian (and hawaiian) eruptions, the small vesicles form during shallow degassing of mainly $\mathrm{H}_{2} \mathrm{O}$ and $\mathrm{S}$, with minor contributions from $F$ and $\mathrm{Cl}$. This stage of degassing occurs at very shallow levels (a few hundred $\mathrm{m}$ ) in the conduit when the magma becomes saturated with these volatiles due to their high solubility in basaltic magma [Gerlach and Graeber, 1985]. Carbon dioxide, however, due to its low solubility in basaltic magma [Dixon et al., 1995], exsolves as pressure decreases during rise of magma from the mantle and during storage in sub-axial magma reservoir or lens, where it can accumulate and coalesce into large bubbles. Subaerial strombolian eruptions probably exsolve these volatile components simultaneously, with large coalesced $\mathrm{CO}_{2}$-rich bubbles triggering eruptive bursts and the shallow-formed $\mathrm{H}_{2} \mathrm{O}$ - and S-rich bubbles forming the smaller vesicles in the pyroclasts. In some locations, like Hawaii, where degassing of $\mathrm{CO}_{2}$ occurs through the summit and degassing of $\mathrm{H}_{2} \mathrm{O}$ and $\mathrm{S}$ occurs at eruptive vents along the rift zones [Gerlach and Graeber, 1985; Gerlach et al., 2002], strombolian activity rarely occurs. Subaerial basaltic eruptions in Hawaii and elsewhere, therefore, almost invariably produce vesicular pyroclasts of spat-

Table 1. Volatile Budgets for E-MORB and N-MORB

\begin{tabular}{|c|c|c|c|c|}
\hline Sample & \multicolumn{2}{|c|}{ MAR Popping Rocks E-MORB } & \multicolumn{2}{|c|}{ Gorda Ridge N-MORB T196-R31 } \\
\hline Vesicles (vol\%) & \multicolumn{2}{|c|}{17.1} & \multicolumn{2}{|c|}{15.6} \\
\hline Pressure (bars) & \multicolumn{2}{|c|}{$383 \pm 28$} & \multicolumn{2}{|c|}{305} \\
\hline $\mathrm{Nb}(\mathrm{ppm})$ & \multicolumn{2}{|c|}{26.2} & \multicolumn{2}{|c|}{3.0} \\
\hline $\mathrm{Ce}(\mathrm{ppm})$ & \multicolumn{2}{|c|}{33.5} & \multicolumn{2}{|c|}{11.0} \\
\hline Volatile $\mathrm{x}$ & $\mathrm{H}_{2} \mathrm{O}(\mathrm{wt} \%)$ & $\mathrm{CO}_{2}(\mathrm{wt} \%)$ & $\mathrm{H}_{2} \mathrm{O}(\mathrm{wt} \%)$ & $\mathrm{CO}_{2}(\mathrm{wt} \%)$ \\
\hline$\rho_{x}$ at $1000^{\circ} \mathrm{C}$ & 0.0661 & 0.1453 & 0.0526 & 0.1179 \\
\hline$(1-F) M_{x, P}$ & 0.61 & 0.60 to 0.82 & 0.16 & 0.07 to 0.095 \\
\hline $\mathrm{M}_{\mathrm{x}, \mathrm{E}}$ & 0.08 & -0.46 to -0.22 & -0.018 & -0.675 to -0.65 \\
\hline$M_{x, D}$ & 0.51 & 0.018 & 0.16 & 0.015 \\
\hline$M_{x, V}$ & 0.025 & 1.04 & 0.018 & 0.76 \\
\hline
\end{tabular}

See text for symbols, data sources, and calculation methods. Negative numbers for $\mathrm{M}_{\mathbf{x}, \mathbf{R}}$ indicate that volatile was added to primary melt. 
ter and scoria, or reticulite [Mangan and Vergniolle, 2000] instead of limu o Pele at primary eruptive vents. These same magmas, after releasing most of their volatiles during transit to the sea, then produce limu o Pele during littoral secondary eruptions.

On the seafloor at depths greater than a few hundred $\mathrm{m}$, only tiny proportions of dissolved $\mathrm{H}_{2} \mathrm{O}$ and $\mathrm{S}$ exsolve and only a few $\mathrm{CO}_{2}$-filled bubbles exsolve in the shallow conduit, due to saturation of $\mathrm{CO}_{2}$ caused by the decrease in pressure as magma migrates upward from the reservoir to the eruptive vent. In mid-ocean ridge basalt, nucleation of bubbles during the final rise to the vent is slow enough that most MORB are supersaturated for their eruption depth [Dixon et al., 1988]. It is because MORB retains its magmatic $\mathrm{H}_{2} \mathrm{O}$ and $\mathrm{S}$ that it contains so few small vesicles. Discharge of large coalesced $\mathrm{CO}_{2}$-filled bubbles can stretch the melt and form dense limu o Pele and angular glass fragments. In a later section, we will develop a more complete budget of volatiles for the Gorda Ridge N-MORB.

\subsection{Bubble Fragmentation}

Fragmentation of the lava bubbles can occur for a variety of reasons. The first is that magmatic gas from the magma continues to inflate the bubble on the lava surface past the point where the thin bubble-wall has become brittle. Some of the limu o Pele fragments that have variable thickness in a mottled pattern probably formed due to over-inflation of the glass bubble. The bubble-wall stretched, became too viscous to stretch evenly, and fragmented. If the bubbles survive intact to this point, they will collapse and fragment as the bubble-wall and the enclosed gas cool in seawater and the pressure inside the bubble decreases below the external pressure. In either case, the initial fragmentation is most likely enhanced by further fragmentation by cooling-contraction granulation of pyroclasts. Some of the limu o Pele fragments that appear to consist of multiple layers of glass (Figure 4c) probably formed during implosion of bubbles, while the glass was still fluid enough to mold against other fragments. A glass bubble could also be blown inside the previous bubble, resulting in double walls.

Implosion of the bubbles during cooling can be quantified if we assume that the volatile phase is entirely $\mathrm{CO}_{2}$. Dixon and Stolper [1995] showed that the exsolved volatile phase in MORB is $95-100 \% \mathrm{CO}_{2}$, so this assumption is a close approximation. In this case, we can calculate the change in density (and volume) as the $\mathrm{CO}_{2}$ cools inside the bubble using the Peng-Robinson cubic equation of state [Peng and Robinson, 1979]. The calculations used a thermodynamic software program, MultiFlash (version 3.0) from Infochem Computer Services Ltd., London. At 250 bars, a magmatic temperature of $1150^{\circ} \mathrm{C}$, and a bottom seawater temperature of $2^{\circ} \mathrm{C}$, supercritical $\mathrm{CO}_{2}$ fluid in the bubble with a density of $0.088 \mathrm{gcm}^{-3}$ contracts to liquid $\mathrm{CO}_{2}$ with a density of $1.031 \mathrm{gcm}^{-3}$ as the glass bubble cools. The $92 \%$ volume decrease of $\mathrm{CO}_{2}$ in the bubble as it cools to ambient temperature leads to collapse and fragmentation of the bubble wall, forming limu o Pele fragments. At 450 bars, magmatic $\mathrm{CO}_{2}$ with density of $0.152 \mathrm{gcm}^{-3}$ contracts to liquid $\mathrm{CO}_{2}$ with density of $1.102 \mathrm{gcm}^{-3}$. At this pressure the volume decrease of the $\mathrm{CO}_{2}$ in the bubble is still $86 \%$. The increasing density of the magmatic $\mathrm{CO}_{2}$ as pressure increases indicates that more magmatic $\mathrm{CO}_{2}$ is required to form the same size glass bubbles at greater depth.

\subsection{Transport and Deposition of Fragments}

The volcaniclastic deposits along the Gorda Ridge, the summit and upper rift zone on Loihi Seamount [Clague et al., 2000, this issue], the axis of the Puna Ridge, and cones in the North Arch, all contain limu o Pele fragments but are mainly comprised of dense angular glass fragments. These glass fragments have similar compositions to the much less abundant limu o Pele fragments in the same samples. Such angular fragment shapes are commonly attributed to thermal-contraction fragmentation [e.g., Batiza and White, 2000]. Many of the fragments have an original glass surface on one side. Particularly along the Gorda Ridge, we have found such dense angular glass fragments, as well as limu o Pele fragments, widely distributed on subdued topography and shallower than nearby lava flows. For example, at NESCA, dense angular glass fragments up to several $\mathrm{mm}$ across were recovered in push-cores on a sediment hill $50 \mathrm{~m}$ above the surrounding lava flow. These dense fragments had to be ejected from the vent into the water column above the vent at least that high, or ejected to a lower height followed by upward transport in a rising plume of seawater heated at the eruption site, as previously proposed by Clague et al. [2000] and Maicher et al. [2001]. We propose that these dense fragments also form during mild strombolian-like activity coupled with thermal-contraction fragmentation in much the same way that limu o Pele is formed. The angular fragments may form by discharge of smaller magmatic gas bubbles that do not sufficiently stretch the lava surface to form thin-walled lava bubbles.

Both types of particles are apparently entrained in thermal plumes of hot water rising over the vent and nearby hot flows. Head and Wilson [2003] modeled the distribution of pyroclasts in a rising thermal plume. Their calculations were for submarine hawaiian fountains produced by very volatile-rich magma and moderately volatile-rich magma, as well as a case for strombolian eruption from foam accu- 
mulated beneath the top of a magma chamber. For the strombolian case, their numerical analysis suggests that the pyroclast/seawater plume should rise only a few hundred $\mathrm{m}$ above the erupting vent, so these lower energy eruptions proposed here should form even smaller plumes. Since these eruptions apparently introduce only small amounts of pyroclasts into the water column, the dense particles presumably settle out of the rising plume according to Stoke's law, so we anticipate that particles deposited nearest the source will be more abundant and larger than at greater distances. The height above the bottom, and therefore the distance the particles might be displaced from their source, will vary with the amount of heat input to the thermal plume and the velocity of ocean currents at appropriate depths. Since the initial stage of a thermal or event plume is unlikely to be observed, the size distribution of glass fragments away from a vent might be one way to quantify the time-varying thermal input into the plume.

\section{PRIOR EVIDENCE FOR MORB VOLATILE LOSS}

Studies over many years of carbon isotope and rare-gas fractionation in MORB [e.g., Pineau and Javoy, 1983; Des Marais and Moore, 1984; Mattey et al., 1984; Staudacher et al., 1989; Fisher and Perfit, 1990; Javoy and Pineau, 1991] and $\mathrm{CO}_{2}$ concentrations in MORB [e.g., Stolper and Holloway, 1988; Gerlach, 1989; Dixon et al., 1988, 1995; Dixon and Stolper, 1995] support the idea that most MORB has degassed a $\mathrm{CO}_{2}$-rich phase that also acts as a carrier for low solubility rare gases, particularly He. The data in these studies is widely interpreted to indicate that magmatic volatiles dominated by $\mathrm{CO}_{2}$ are exsolved from MORB magma as it rises from the mantle and the exsolved volatiles may be accumulated and stored as bubbles when the magma is stored, however briefly, in crustal magma chambers [e.g., Gerlach and Graber, 1985; Bottinga and Javoy, 1989a; Gerlach, 1989].

Exsolution of magmatic volatiles and magma buoyancy generated by bubble growth in rising magma is now widely thought to drive magma ascent prior to subaerial eruptions [e.g., Sparks, 1978; Wilson and Head, 1981] and most probably submarine basaltic eruptions as well [e.g. Bottinga and Javoy, 1989a, 1989b, 1990; Head and Wilson, 2003]. Bottinga and Javoy [1989a] proposed that MORB magmas undergo two stages of bubble nucleation and growth with the first occurring as magma rises through the mantle and the second during eruption. They also proposed that volatiles exsolved during the primary stage of ascent accumulated in magma chambers below the ridge axis and that without the development of this separate volatile rich zone in the magma chamber no eruption occurs. Sarda and
Graham [1991] discussed the possibility that exsolved volatile accumulation could lead to eruptions where "volatile-charged products may form."

Our analysis shows that N-MORB eruptions produce pyroclasts of limu o Pele during mildly explosive strombolian activity in which large coalesced bubbles of mainly supercritical $\mathrm{CO}_{2}$ fluid rise through the otherwise dense magma in the vent. Our results are completely in accord with the geochemical studies noted above, but extend those studies by proposing an eruptive mechanism by which the "missing" exsolved volatile phase escapes from MORB magma.

\section{MORB VOLATILE EXSOLUTION HISTORY}

\subsection{Conceptual Framework}

Does MORB contain enough magmatic volatiles that can exsolve and accumulate to drive the strombolian-like style of eruptions we have proposed? Our interpretation that MORB limu o Pele from Gorda Ridge forms during vigorous bubbling at the vent and formation of a low pyroclastic eruption column implies that MORB magma contains significantly more gas on eruption than one would infer from the $<1 \%$ small vesicles contained in typical MORB pillow basalt [e.g., Moore, 1979]. We can construct a budget of volatiles by first estimating the Primary volatile contents, $M_{x, P}$ or the mass proportion of volatile $x$ in melt as it separates and rises in the mantle. Since $\mathrm{CO}_{2}$ exsolves from basaltic magma as it rises through the mantle and while it crystallizes some fraction $F$ in magma chambers, there is a component that we call Exsolved volatiles, or $\mathrm{M}_{\mathrm{x}, \mathrm{E}}$, that may be separated from the melt phase. It is not necessary to independently estimate the percent crystallization $F$, since the term (1-F) $\mathrm{M}_{\mathrm{x}, \mathrm{P}}$ represents the volatiles in the erupted melts if they had not exsolved any volatiles; these concentrations can be calculated from trace element contents of the erupted magmas, as described below. The volatile component retained in the lava upon eruption is divided into an Vesicle-filling, or $\mathbf{M}_{\mathbf{x}, \mathrm{V}}$ and a Dissolved component, or $M_{x, D}$. A final component consists of volatiles lost during the eruption into the water column; it cannot be determined readily, but may consist mainly of the volatiles separated during rise and storage in a magma reservoir and will be determined as part of the "exsolved, or $\mathrm{M}_{\mathrm{x}, \mathrm{E}}$, component." These volatile components are schematically shown in Figure 7 and are related as follows:

$$
(1-\mathrm{F}) \mathrm{Mx}, \mathrm{P}=(\mathrm{Mx}, \mathrm{E}+\mathrm{Mx}, \mathrm{V}+\mathrm{Mx}, \mathrm{D})
$$

We use the observation that $\mathrm{CO}_{2}$ behaves as an incompatible element having a constant ratio to other incompatible 


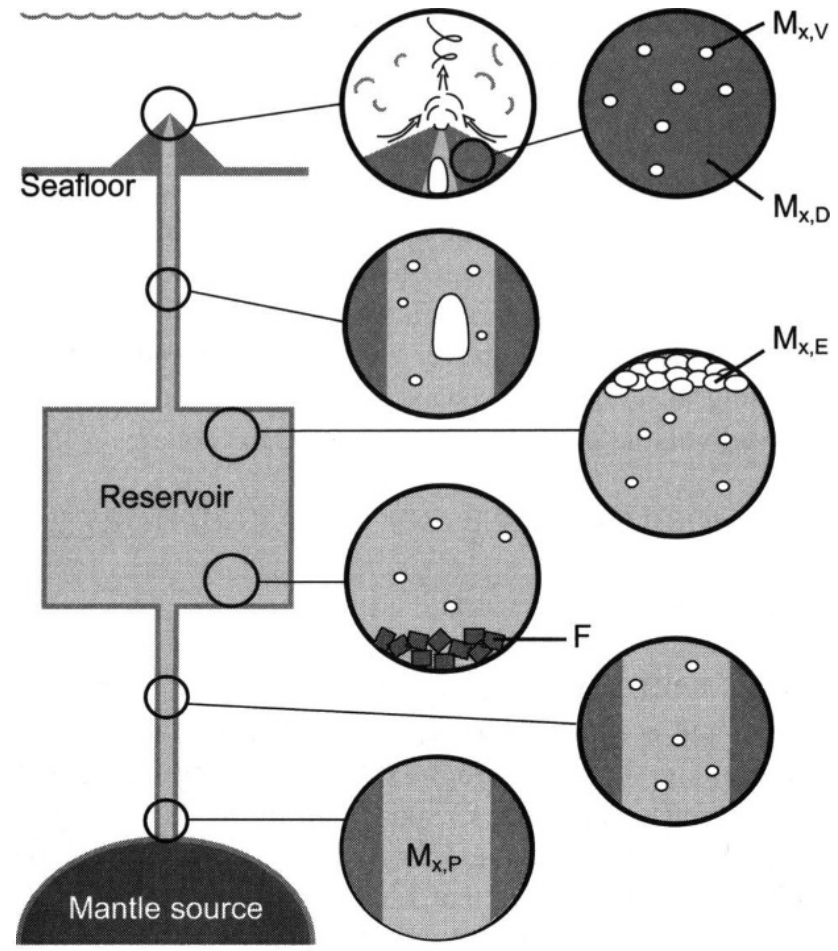

Figure 7. Schematic diagram describing the volatile evolution in MORB magma as it ascends through the upper mantle, pauses in a magma reservoir, ascends to the seafloor, and erupts. White circles and blebs are volatile bubbles, light gray is melt, and dark gray is rock. Upper left exploded view shows formation of limu o Pele during mild strombolian activity with fragments carried upwards in the water column by a rising, heated, turbulent plume of seawater. $M_{x, P}$ is the mass of volatile $x$ in primary magma, $M_{x, E}$ is the mass of volatile $\mathrm{x}$ exsolved during transport and storage, $M_{x, D}$ is the mass of volatile $x$ dissolved in the quenched melt, $M_{x, V}$ is mass of volatile $x$ contained in vesicles in the erupted lava, and $F$ is the proportion of fractional crystallization to form the erupted lava from the primary magma. See text for discussion of model and Table 1 for examples of calculated volatile budgets for E-MORB and N-MORB.

elements, such as $\mathrm{Nb}$ [Saal et al., 2002; Hauri et al., 2002], and measured $\mathrm{Nb}$ concentrations to determine the $\mathrm{CO}_{2}$ content in the primary magma, corrected for subsequent fractionation, (1-F)M $\mathrm{M}_{\mathrm{x}, \mathrm{E}}$ for $\mathrm{x}=\mathrm{CO}_{2}$. The $\mathrm{H}_{2} \mathrm{O} / \mathrm{Ce}=180$ for Pacific and south Atlantic MORB [Michael, 1995], so we can determine (1-F) $\mathrm{M}_{\mathrm{x}, \mathrm{E}}$ for $\mathrm{x}=\mathrm{H}_{2} \mathrm{O}$ from the Ce content of the erupted lava. We measure the dissolved $\mathrm{M}_{\mathrm{x}, \mathrm{D}}$ in the glass for both $\mathrm{H}_{2} \mathrm{O}$ and $\mathrm{CO}_{2}$ using FTIR. The vesicle-filling $\mathrm{M}_{\mathrm{x}, \mathrm{V}}$ can be estimated by calculating the volatiles required to form the vesicles retained in the lava sample. In the case of MORB, the mixed volatile phase in the vesicles is $95-100 \%$ $\mathrm{CO}_{2}$ [Dixon and Stolper, 1995]; we have used a conserva- tive $95 \%$. The difference between the primary volatile content, corrected for crystallization, and the sum of the dissolved and vesicle-filling volatiles is the volatile content lost during rise from the mantle, storage, and eruption that we have called the exsolved component.

\subsection{MAR E-MORB Popping Rocks}

One example of this type of reconstruction is based on the so-called "popping rocks" recovered from the Mid-Atlantic Ridge (MAR) [Hekinian et al., 1973; Pineau et al., 1976; Sarda and Graham, 1990; Javoy and Pineau, 1991; Gerlach, 1991; Graham and Sarda, 1991]. The popping rocks are enriched- or E-MORB containing $0.63 \mathrm{wt} \% \mathrm{~K}_{2} \mathrm{O}$ and up to 17 volume\% vesicles. The samples were recovered from $3770 \pm 275 \mathrm{~m}$ depth or a pressure of $383 \pm 28$ bars. Following suggestions from Gerlach [1991], Graham and Sarda [1991] calculated that the popping rock magma had $\mathrm{CO}_{2}=0.85 \mathrm{wt} \%$ and $\mathrm{H}_{2} \mathrm{O}=0.59 \mathrm{wt} \%$ at $1000^{\circ} \mathrm{C}$ with a melt density $\mathrm{p}_{\mathrm{m}}=2.697 \mathrm{gcm}^{-3}$ using non-ideal conditions and assuming that mixing of a binary $\left(\mathrm{H}_{2} \mathrm{O}-\mathrm{CO}_{2}\right)$ vapor phase is ideal. The $1000^{\circ} \mathrm{C}$ temperature is preferable to a higher magmatic temperature, since it approximates the temperature when the melt becomes rigid and the vesicles stop contracting as the lava cools from a magmatic temperature of about $1200^{\circ} \mathrm{C}$. We have recalculated the content of an ideally mixed supercritical $\mathrm{CO}_{2}$ and $\mathrm{H}_{2} \mathrm{O}$ fluid required to produce the observed volume of vesicles using densities calculated with the Peng-Robinson cubic equation of state [Peng and Robinson, 1979], since the ideal gas law is inappropriate for supercritical fluids, such as $\mathrm{CO}_{2}$ and $\mathrm{H}_{2} \mathrm{O}$ at these conditions. The densities of supercritical $\mathrm{CO}_{2}$ and $\mathrm{H}_{2} \mathrm{O}$ at these conditions are listed in Table 1 . Simply combining the densities and the volume proportions of the different components allows direct calculation of $\mathrm{M}_{\mathrm{x}, \mathrm{V}}$. The results in Table 1 show that $\mathrm{M}_{\mathrm{x}, \mathrm{V}}$ for $\mathrm{x}=\mathrm{CO}_{2}$ is significantly greater than determined using the ideal gas law.

To calculate the primary volatile contents of the melt (1-F) $\mathrm{M}_{\mathrm{x}, \mathrm{P}}$, we use the Ce content of the popping rocks of $33.5 \mathrm{ppm}$ [Bougault et al., 1988], and $\mathrm{H}_{2} \mathrm{O} / \mathrm{Ce}=183$ determined for southern Mid-Atlantic MORB (unfortunately not for the region where the popping rock was recovered) [Michael, 1995], and the $\mathrm{Nb}$ content of $26.2 \mathrm{ppm}$ [Bougault et al., 1988] and $\mathrm{CO}_{2} / \mathrm{Nb}$ covering the range $230 \pm 55$ [Saal et al., 2002] to $314 \pm 125$ [Hauri et al., 2002].

The dissolved components, $\mathrm{M}_{\mathrm{x}, \mathrm{D}}$, were measured by FTIR [J. Dixon, cited in Graham and Sarda, 1991]. Substituting into the equation above, we solve for $\mathrm{M}_{\mathrm{x}, \mathrm{E}}$. The calculations, summarized in Table 1, suggest that the popping rocks have gained some $\mathrm{CO}_{2}$ during rise and storage. 
This increase in $\mathrm{CO}_{2}$ suggests accumulation of a volatile component consisting mostly of $\mathrm{CO}_{2}$ supercritical fluid. The imbalance in water probably reflects uncertainty in the $\mathrm{H}_{2} \mathrm{O} / \mathrm{Ce}$ for this segment of the Mid-Atlantic Ridge.

\subsection{Gorda Ridge N-MORB}

Gorda Ridge MORB contain between 0.63 and $9.36 \mathrm{ppm}$ $\mathrm{Nb}$ and between 5.0 and $16.94 \mathrm{ppm}$ Ce for lavas with glass $\mathrm{MgO}$ content ranging from about 7.3 to $9.1 \mathrm{wt} \%$ [Davis and Clague, 1987, 1990; Davis et al., 1998; Davis and Clague, unpublished data). We calculate that (1-F) $\mathrm{M}_{\mathrm{x}, \mathrm{P}}$ for $\mathrm{x}=\mathrm{CO}_{2}$ ranges from lows between 0.015 and $0.020 \mathrm{wt} \%$ to highs between 0.215 and $0.294 \mathrm{wt} \%$ and that $(1-\mathrm{F}) \mathrm{M}_{\mathrm{x}, \mathrm{P}}$ for $\mathrm{x}=\mathrm{H}_{2} \mathrm{O}$ ranges from lows between 0.086 and $0.094 \mathrm{wt} \%$ to highs between 0.280 and $0.305 \mathrm{wt} \%$.

Among these many samples, only a few have abundant vesicles that allow reconstruction of $\mathrm{M}_{\mathrm{x}, \mathrm{V}}$. We recovered four vesicular MORB samples from the Gorda Ridge using the MBARI ROV Tiburon in August 2000 on dive T296 (Figure 1) [Clague et al., 2001]. The lava fragments were recovered from talus on the inner northern wall of a breached crater in a small volcano located near the northern end of Escanaba Trough at $41.1754^{\circ} \mathrm{N}, 127.5186^{\circ} \mathrm{W}$. The most vesicular sample, T196-R31 (Figure 8), contains 15.6 volume $\%$ vesicles and was collected at $3006 \mathrm{~m}$ depth (305 bars). The top of the cone, the shallowest possible eruption depth, is $2930 \mathrm{~m}$. In contrast to the popping rocks, the Gorda Ridge sample, and several other slightly less vesicular samples from the same location, are depleted N-MORB

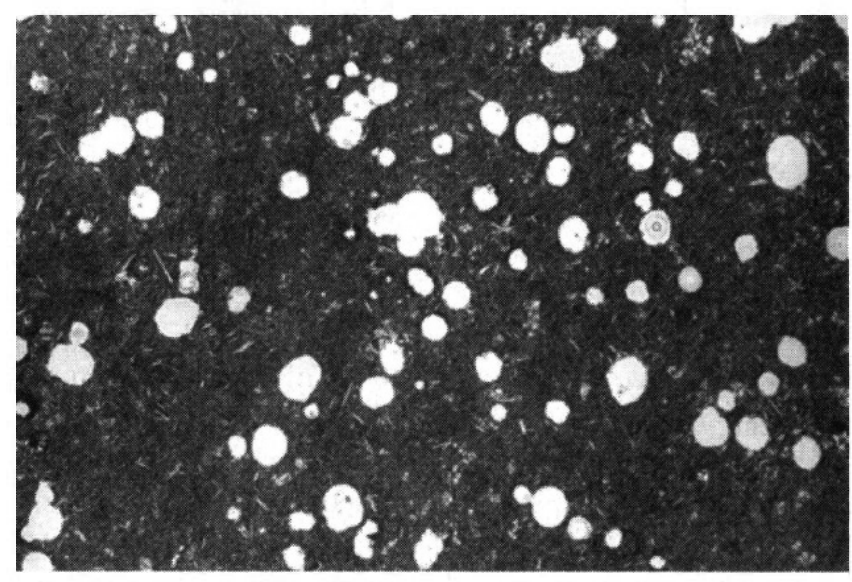

Figure 8. Photograph of thin section (long dimension $2.8 \mathrm{~cm}$ ) of vesicular N-MORB sample T196-31 collected from $3005 \mathrm{~m}$ depth on a small cone at the north end of Escanaba Trough, southern Gorda Ridge. Sample is holocrystalline with no glass rind and has 15.6 volume $\%$ vesicles.

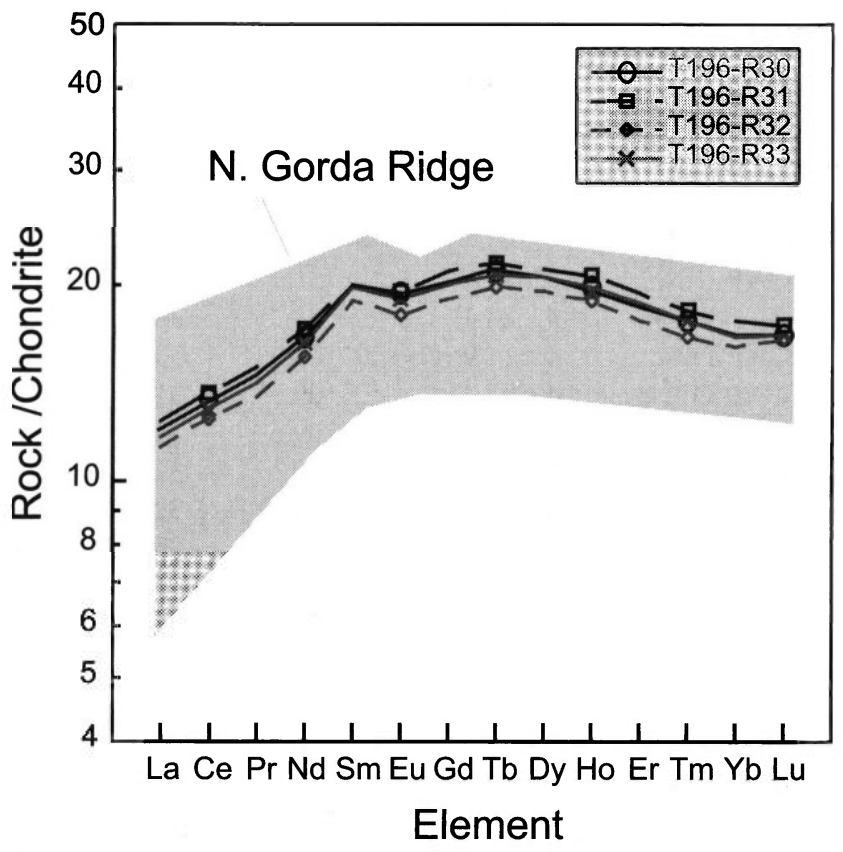

Figure 9. Chondrite-normalized rare earth plot of 4 vesicular basalt samples from Gorda Ridge showing that they are all NMORB with light-REE-element depleted patterns. Normalizing values from Boynton [1984].

as seen by their strongly depleted light-REE patterns (Figure 9).

We repeated the calculations done for the popping rocks for the vesicular N-MORB from Gorda Ridge, except that none of these samples has a glass rind, so $\mathrm{M}_{\mathrm{x}, \mathrm{D}}$ upon eruption and quenching cannot be directly measured using FTIR. However, we can estimate these values using data for 15 other MORB glasses from the axis of Gorda Ridge, determined by FTIR and presented in Table 2 . These samples have $\mathrm{H}_{2} \mathrm{O}$ (Table 1) that is correlated to Ce [data from Davis et al., 1987] with a $\mathrm{H}_{2} \mathrm{O} / \mathrm{Ce}=165 \pm 21$, statistically identical to the ratio of $180 \pm 30$ proposed by Michael [1995] for Pacific MORB. The 15 ridge axis glasses average 147 ppm $\mathrm{CO}_{2}$, which we have used as a rough estimate of $\mathrm{M}_{\mathrm{x}, \mathrm{D}}$ for $\mathrm{x}=\mathrm{CO}_{2}$. The entire volatile budget is summarized in Table 1.

The volatile content of the magma upon eruption is the sum of the dissolved and exsolved components, or 0.18 $\mathrm{wt} \% \mathrm{H}_{2} \mathrm{O}$ and $0.78 \mathrm{wt} \% \mathrm{CO}_{2}$ which contrasts with our calculated (1-F) $\mathrm{M}_{\mathrm{x}, \mathrm{P}}$ for $\mathrm{x}=\mathrm{CO}_{2}$ of only 0.07 to $0.095 \%$. The discrepancy indicates that the vesicular samples have accumulated gas exsolved from 8-11 times as much magma. This is direct evidence that $\mathrm{M}_{\mathrm{x}, \mathrm{P}}$, particularly for $\mathrm{x}=\mathrm{CO}_{2}$, in mid-ocean ridge magma exsolves during transport and storage, migrates separately from the melt phase, accumulates; 
Table 2. Volatile and Trace Element Data for Gorda Ridge MORB Glasses

\begin{tabular}{|c|c|c|c|c|c|c|c|c|c|c|}
\hline Sample & $\begin{array}{l}\text { Latitude } \\
\left({ }^{\circ} \mathrm{N}\right)\end{array}$ & $\begin{array}{l}\text { Longitude } \\
\left({ }^{\circ} \mathrm{W}\right)\end{array}$ & $\begin{array}{l}\text { Depth } \\
(\mathrm{m})\end{array}$ & $\mathrm{Mg} \#$ & $\begin{array}{l}\mathrm{Nb} \\
(\mathrm{ppm})\end{array}$ & $\begin{array}{l}\mathrm{Ce} \\
(\mathrm{ppm})\end{array}$ & $\begin{array}{l}\mathrm{H}_{2} \mathrm{O} \\
\left(w t^{\%}\right)\end{array}$ & $\begin{array}{l}\mathrm{H}_{2} \mathrm{O} \\
+/-, \mathrm{N} \\
\end{array}$ & $\begin{array}{l}\mathrm{CO}_{2} \\
(\mathrm{ppm})\end{array}$ & $\begin{array}{l}\mathrm{CO}_{2} \\
+/-, \mathrm{N} \\
\end{array}$ \\
\hline KK83NP-D1-8 & $42^{\circ} 56.6^{\prime}$ & $126^{\circ} 37.5^{\prime}$ & 3230 & 60.4 & - & 13.8 & 0.262 & $0.006,2$ & 133 & 11,2 \\
\hline KK83NP-D3-4 & $42^{\circ} 54.4^{\prime}$ & $126^{\circ} 40.3^{\prime}$ & 3158 & 62.5 & - & 12.1 & 0.234 & & 151 & 03,1 \\
\hline KK83NP-D4-15 & $42^{\circ} 45.4^{\prime}$ & $126^{\circ} 42.0^{\prime}$ & 3223 & 69.4 & 0.63 & 5.2 & 0.088 & & 133 & 16,1 \\
\hline KK83NP-D6-12 & $42^{\circ} 34.3^{\prime}$ & $126^{\circ} 51.1^{\prime}$ & 3288 & 58.8 & - & 16.5 & 0.274 & $0.013,3$ & 139 & 09,3 \\
\hline KK83NP-D7-4 & $42^{\circ} 28.4^{\prime}$ & $126^{\circ} 53.3^{\prime}$ & 3658 & 62.1 & - & 15.8 & 0.280 & $0.012,2$ & 156 & 16,2 \\
\hline KK83NP-D9-1 & $42^{\circ} 14.9^{\prime}$ & $127^{\circ} 04.6^{\prime}$ & 3048 & 63.6 & - & 8.0 & 0.114 & $0.000,2$ & 145 & 11,2 \\
\hline KK83NP-D11-8 & $42^{\circ} 07.2^{\prime}$ & $127^{\circ} 09.5^{\prime}$ & 3108 & 60.9 & 2.75 & 12.0 & 0.215 & $0.004,2$ & 164 & 11,2 \\
\hline KK83NP-D12-2 & $42^{\circ} 02.1^{\prime}$ & $127^{\circ} 09.6^{\prime}$ & 3425 & 60.8 & - & 12.0 & 0.202 & & 145 & 14,1 \\
\hline KK83NP-D13-3 & $41^{\circ} 48.2^{\prime}$ & $127^{\circ} 10.1$ & 3275 & 64.8 & - & 8.4 & 0.126 & & 168 & 10,1 \\
\hline KK83NP-D14-8 & $41^{\circ} 41.7^{\prime}$ & $127^{\circ} 13.9^{\prime}$ & 3280 & 64.1 & - & 9.9 & 0.141 & $0.006,2$ & 157 & 15,2 \\
\hline KK83NP-D16-1 & $41^{\circ} 31.3^{\prime}$ & $127^{\circ} 27.4^{\prime}$ & 3340 & 56.5 & - & 16.3 & 0.278 & $0.009,2$ & 134 & 11,2 \\
\hline KK83NP-D17-10 & $41^{\circ} 27.7^{\prime}$ & $127^{\circ} 13.5^{\prime}$ & 1703 & 62.0 & - & 12.3 & 0.216 & & 158 & 12,1 \\
\hline T196-R31 & $41^{\circ} 10.5^{\prime}$ & $127^{\circ} 31.1^{\prime}$ & 3005 & 62.8 & 3.03 & 11.03 & - & - & - & - \\
\hline L685NC-D36-10 & $40^{\circ} 59.0^{\prime}$ & $127^{\circ} 30.2^{\prime}$ & 3200 & 60.8 & $6.8^{*}$ & $16.5^{*}$ & 0.253 & & 122 & 14,1 \\
\hline L685NC-D36-11 & $40^{\circ} 59.0^{\prime}$ & $127^{\circ} 30.2^{\prime}$ & 3200 & 60.8 & $6.8^{*}$ & $16.5^{*}$ & 0.255 & $0.017,2$ & 123 & 12,2 \\
\hline L685NC-D31-11 & $40^{\circ} 46.4^{\prime}$ & $127^{\circ} 30.8^{\prime}$ & 3250 & 65.9 & $3.9^{*}$ & $8.0^{*}$ & 0.125 & & 182 & 15,1 \\
\hline L585NC-D33-2C & $42^{\circ} 45.4^{\prime}$ & $128^{\circ} 06.1^{\prime}$ & $\sim 1900$ & 61.2 & - & 14.0 & 0.204 & $0.001,3$ & 127 & 07,3 \\
\hline L585NC-D35-10 & $42^{\circ} 26.0^{\prime}$ & $127^{\circ} 40.6^{\prime}$ & $\sim 1950$ & 69.1 & - & 6.67 & 0.119 & $0.006,2$ & 161 & 16,2 \\
\hline
\end{tabular}

$\mathrm{Nb}, \mathrm{Ce}$ and $\mathrm{Mg} \#\left(\left(100 \mathrm{Mg} /\left(\mathrm{Mg}+\mathrm{Fe}^{2+}\right)\right.\right.$ calculated using $\left.\mathrm{Fe}^{2+}=0.9 \mathrm{Fe}^{\mathrm{T}}\right)$ from Davis and Clague [1987], Davis et al. [1998], Davis and Clague [2000], or Davis and Clague [unpublished data]. $\mathrm{H}_{2} \mathrm{O}$ and $\mathrm{CO}_{2}$ by FTIR are the volatile component dissolved in glass. $\mathrm{N}$ indicates number of analyses. * indicates trace element data are average for 24 and 6 samples from same sites as L685NC-D36 and -D31, respectively.

it presumably coalesces to form the large bubbles needed to drive mild strombolian activity. This finding is consistent with the widespread view that most MORB has degassed $\mathrm{CO}_{2}$. In this case, the coalesced exsolved volatile phase may have accumulated in a lava pond in the volcanic cone, since such flat-topped cones are likely to form as overflowing lava ponds [Clague et al., 2000b].

The calculated (1-F) $\mathrm{M}_{\mathrm{x}, \mathrm{P}}$ for $\mathrm{x}=\mathrm{CO}_{2}$ of 0.07 to $0.095 \mathrm{wt} \%$ minus the $\mathrm{M}_{\mathrm{x}, \mathrm{D}}$ of $0.018 \mathrm{wt} \%$ would exsolve to form $1.2-1.7 \mathrm{vol} \%$ vesicles, a somewhat greater vesicularity than normally observed in N-MORB from these depths. This discrepancy again supports the idea that supercritical $\mathrm{CO}_{2}$ liquid exsolves from N-MORB during transport and storage, rather than during shallow devolatization. However, the results for both the MAR popping rocks and the Gorda Ridge N-MORB sample demonstrate that combining vesicle volatile contents with dissolved volatile contents can lead to an overestimation of initial magmatic volatile contents.

\section{WATER COLUMN EVENT PLUMES}

The exsolved magmatic $\mathrm{CO}_{2}$ supercritical fluid that forms the limu o Pele bubbles is discharged directly into the seawater above the eruption site. Numerous studies, mainly by a group of researchers at NOAA, have mapped what they call event plumes that accompany seismic swarms along the mid-ocean ridge system [e.g., Baker et al., 1987, 1989, 1998; Kelley et al., 1998; Lupton et al., 1999a, b]. These event plumes are characterized by excess heat and ${ }^{3} \mathrm{He}$ [Lupton et al., 1999a, 1999b] as well as a wide range of geochemical and particulate markers [e.g., Baker et al., 1998; Feeley et al., 1998; Kelley et al., 1998]. Some tracers in the plumes are conservative (such as ${ }^{3} \mathrm{He}$ ), allowing them to be tracked over long distances [Lupton, 1996, 1998].

Interpretation of the origin of these plumes leans heavily toward a massive non-magmatic hydrothermal discharge at the beginning of a submarine eruption [Baker, 1998]. In support of a direct eruptive volatile component, as we propose here, Baker [e.g.,1995] notes that magmatic volatile input to plumes increases ${ }^{3} \mathrm{He} /$ heat ratios following eruptions and Rubin [1997] suggests that metals and metalloids in plumes may be contributed by magmatic degassing. Based on the widespread occurrence of limu o Pele fragments along at least one mid-ocean ridge, the Gorda Ridge, we propose that one component of event plumes consists of magmatic volatiles discharged directly into the water column during submarine strombolian activity at the erupting vents. The magmatic volatiles would mainly be $\mathrm{CO}_{2}$, as well as the $\mathrm{CH}_{4}, \mathrm{H}_{2}$, and ${ }^{3} \mathrm{He}$ observed in the plumes [Kelley et al., 1998]. The heat in the plume may be mainly derived from conductive cooling of erupted lava, as explored by Baker [1998]. The variable ratio of heat $/ 3 \mathrm{He}$ observed in different event plumes [Lupton et al., 1999a, 1999b] may 
reflect variations in the volume of erupted lava to discharged magmatic volatile phase. In any case, magmatic volatiles are transferred to the oceans by several pathways, one of which is the direct discharge of a separated volatile phase during strombolian activity along mid-ocean ridges.

\section{MID-OCEAN RIDGE MAGMA CHAMBERS}

There are several implications of the widespread occurrence of submarine strombolian basaltic eruptions since the separated gas phase is first accumulated in the magma chambers and is then discharged into the surrounding seawater during eruptions. It has been widely documented that crustal magma chambers underlying the mid-ocean ridge system produce strong seismic reflections [e.g., McClain et al., 1985; Detrick et al., 1987; Rohr et al., 1988; Sinton and Detrick, 1992] that suggest a large velocity contrast between the overlying rock and the underlying magma. If magmatic gas accumulates in magma chambers, it must buoyantly rise and coalesce beneath the rigid lid of the magma chamber. The strong seismic reflections may actually be mapping the distribution of low-density mixtures of magma and separated gas bubbles that grew and coalesced as they rose in the magma. Such a model suggests that the density and therefore the seismic velocity of a thin layer at the top of the magma chamber could be very low. Present seismic models [e.g., Sinton and Detrick, 1992] of the size and shape of mid-ocean ridge magma chambers do not consider such a layer.

\section{CONCLUDING REMARKS}

The results from this study have application to other deep-sea basaltic magmas, including back-arc basin basalts [Gill et al., 1990], ocean island tholeiitic basalt [see Clague et al., this volume], and strongly alkalic basalt [e.g., Clague et al., 1990, 2002]. All of these basalt types contain significantly higher concentrations of primary volatiles than $\mathrm{N}$ MORB which makes it more likely that volatile concentrations required to drive strombolian eruptions [as outlined by Head and Wilson, 2003] will be attained by volatile accumulation during transport and storage of these magmas. Pyroclastic basaltic eruptions, similar to subaerial strombolian eruptions because they are driven by release of exsolved and coalesced magmatic volatiles appear to have no depth or compositional limitation in the oceans.

Acknowledgments. The authors thank Captains Mark Vandenberg and Ian Young and the crew of the Western Flyer, chief pilots Dale Graves and Buck Reynolds and the entire group of Tiburon pilots, and the scientific parties for making the Gorda
Ridge cruises so successful. We thank Ed Peltzer for assistance calculating the density of supercritical $\mathrm{CO}_{2}$ fluids and Jenny Paduan for skillfully preparing many of the figures. The manuscript benefited from reviews by Margaret Mangan, James White and an anonymous reviewer that greatly focused the presentation here. This study was supported by the David and Lucile Packard Foundation through a grant to the Monterey Bay Aquarium Research Institute.

\section{REFERENCES}

Baker, E.T., Characteristics of hydrothermal discharge following a magmatic intrusion, in Hydrothermal vents and processes, ed. by L.M. Parsons, C.L. Walker, and D.R. Dixon, Geol. Soc. Spec. Pub. No 87, 65-76, 1995.

Baker, E.T., G.J. Massoth, and Feeley, R.A., Cataclysmic hydrothermal venting on the Juan de Fuca Ridge, Nature, 329, 149-151, 1987.

Baker, E.T., J.W. Lavelle, R.A. Feeley, G.J. Massoth, S.L. Walker, and J.E. Lupton, Episodic venting of hydrothermal fluids from the Juan de Fuca Ridge, J. Geophys. Res., 94, 9237-9250, 1989.

Baker, E.T., Patterns of event and chronic hydrothermal venting following a magmatic intrusion: new perspectives from the 1996 Gorda Ridge eruption, Deep-Sea Res. II, 45, 2599-2618, 1998.

Ballard, R.D., R.T. Holcomb, and T.H. van Andel, The Galapagos Rift at $86^{\circ} \mathrm{W}$. 3. Sheet flows, collapse pits, and lava lakes of the rift valley, J. Geophys. Res., 84, 5407-5422, 1979.

Batiza, R., and J.D.L. White, Submarine lavas and hyaloclastite, in Encyclopedia of Volcanoes, ed. by H. Sigurdsson, Academic Press, San Diego, 361-381, 2000.

Bischoff, J.L., and R.J. Rosenbauer, An empirical equation of state for hydrothermal seawater, Am. J. Sci., 285, 725-763, 1988

Blackburn, E.A., L. Wilson, and R.S.J. Sparks, Mechanisms and dynamics of Strombolian activity, J. Geol. Soc. London, 132, 429-440, 1976.

Bottinga, Y., and M. Javoy, MORB degassing: evolution of $\mathrm{CO}_{2}$, Earth Planet. Sci. Lett., 95, 215-225, 1989a.

Bottinga, Y., and M. Javoy, Mid-ocean ridge basalt degassing: bubble nucleation, J. Geophys. Res., 95, 5125-5131, $1989 \mathrm{~b}$.

Bottinga, Y., and M. Javoy. MORB degassing: bubble growth and ascent, Chem. Geol., 81, 255-270, 1990.

Bougault, H., L. Demitriev, J.G. Schilling, A. Sobolev, J.L. Joron, and H.D. Needham, Mantle heterogeneity from trace elements: MAR triple junction near $14^{\circ} \mathrm{N}$, Earth Planet. Sci. Lett., 88, $27-$ 36, 1988.

Boynton, W.V., Cosmochemistry of the rare earth elements: Meteorite studies, in Rare earth element Geochemistry, edited by P. Henderson, Elsevier, N.Y, 63-114, 1984.

Byers, C.D., M.O. Garcia, and D.W. Muenow, Volatiles in basaltic glasses from the East Pacific Rise at $21^{\circ} \mathrm{N}$ : implications for MORB sources and submarine lava flow morphology, Earth Planet. Sci. Lett., 79, 9-20, 1986.

Chadwick, W.W., Jr., R.W. Embley, and T.M. Shank, The 1996 Gorda Ridge eruption: geologic mapping, sidescan sonar, and 
SeaBeam comparison results, Deep-Sea Res. II, 45, 2547-2569, 1998.

Clague, D.A., A.S. Davis, J.L. Bischoff, J.E. Dixon, and R. Geyer, Lava bubble-wall fragments formed by submarine hydrovolcanic explosions on Loihi Seamount and Kilauea Volcano, Bull. Volcanol., 61, 437-449, 2000a.

Clague, D.A., R.T. Holcomb, J.M. Sinton, R.S. Detrick, and M.E. Torresan, Pliocene and Pleistocene alkalic flood basalts on the seafloor north of the Hawaiian Islands, Earth. Planet. Sci. Lett., 98, 175-191, 1990.

Clague, D.A., and M.L. Holmes, The geology and mineral potential of the Gorda Ridge, in Geology and resource potential of the continental margin of western North America and adjacent ocean basins - Beaufort Sea to Baja California, ed. by Scholl, D.W., Grantz, A. and Vedder, J.G., Circum-Pacific Council for Energy and Mineral Resources Earth Sci. Series, 6, 563-580, 1987.

Clague, D.A., J.G. Moore, J.E. Dixon, and W.B. Friesen, Petrology of submarine lavas from Kilauea's Puna Ridge, Hawaii, $J$. Petrol., 36, 299-349, 1995.

Clague, D.A., J.G. Moore, and J.R. Reynolds, Formation of submarine truncated volcanic cones in Hawaii. Bulletin of Volcanology , v. 62, p. 214-233, 2000b.

Clague, D.A., and P. Rona, Geology of the GR-14 site on the northern Gorda Ridge, in Gorda Ridge: A frontier area in the United States Exclusive Economic Zone, ed. by G.R. McMurray. New York, Springer-Verlag, p. 31-50. 1989.

Clague, D.A., K. Uto, K. Satake, and A.S. Davis, Eruption style and flow emplacement in the submarine North Arch volcanic field, Hawaii, in Hawaiian Volcanoes: Deep Underwater Perspectives, ed. E. Takahashi (et al.), Geophysical Monograph 128, Am. Geophys. Union, Washington D.C., 65-84, 2002.

Clague, D.A., R. Zierenberg, A. Davis, S. Goffredi, J. McClain, N. Maher, E. Olsen, V. Orphan, S. Ross, and K. von Damm, MBARI's 2000 expedition to the Gorda Ridge, RIDGE Events, $11(3), 5-12,2001$.

Davis, A.S., and D.A. Clague, Geochemistry, minerology, and petrogenesis of basalt from the Gorda Ridge, J. Geophys. Res., 92, 10467-10483, 1987.

Davis, A.S., and D.A. Clague, Gabbroic xenoliths from the northern Gorda Ridge: Implications for magma chamber processes under slow-spreading centers, J. Geophys. Res., 95, 10885-10905, 1990.

Davis, A.S., and D.A. Clague, President Jackson Seamounts, northern Gorda Ridge: tectonomagmatic relationship between on- and off-axis volcanism, J.Geophys. Res., 105, 27939-27956, 2000.

Davis, A.S., D.A. Clague, and W.F. Friesen, Petrology and mineral chemistry of basalt from Escanaba Trough, southern Gorda Ridge, U.S. Geol. Surv. Bull., 2022, 153-170, 1994.

Davis, A.S., D.A. Clague, and W.M. White, Geochemistry of basalt from Escanaba Trough: Evidence for sediment contamination, J. Petrol., 39, 841-858, 1998.

Des Marais, D.J., and J.G. Moore, Carbon and its isotopes in midoceanic basaltic glasses, Earth Planet. Sci. Lett., 69, 43-57, 1984.

Detrick, R.S., P. Buhl, E. Vera, J. Mutter, J. Orcutt, J. Madsen, and T. Brocher, Multichannel seismic imaging of a crustal magma chamber along the East Pacific Rise, Nature, 326, 35-41, 1987.
Dixon, J.E., and E.M. Stolper, An experimental study of water and carbon dioxide solubilities in mid-cean ridge basaltic liquids. Part II: Applications to degassing, J. Petrol. 36, 1633-1646, 1995.

Dixon, J.E., E.M. Stolper, and J.R. Delaney, Infrared spectroscopic measurements of $\mathrm{CO}_{2}$ and $\mathrm{H}_{2} \mathrm{O}$ in Juan de Fuca Ridge basaltic glasses, Earth Planet. Sci. Lett., 90, 87-104, 1988.

Dixon, J.E., E.M. Stolper, and J.R. Holloway, An experimental study of water and carbon dioxide solubilities in mid-cean ridge basaltic liquids. Part I: Calibration and solubility models, $J$. Petrol., 36, 1607-1631, 1995.

Feeley, R.A., E.T. Baker, G.T. Lebon, J.F. Gendron, G.J. Massoth, and C.W. Mordy, Chemical variations of hydrothermal plume particles in the 1996 Gorda Ridge event and chronic plumes, Deep-Sea Res. II, 45, 2637-2664, 1998.

Fisher, D.E., and M.R. Perfit, Evidence from rare-gases for magma-chamber degassing of highly evolved mid-ocean-ridge basalt, Nature, 343, 450-452, 1990.

Fouquet, Y., J.-P. Eissen, H. Ondreas, F. Barriga, R. Batiza, and L. Danyushevsky, Extensive volcaniclastic deposits at the MiAtlantic Ridge axis: results of deep-water basaltic explosive volcanic activity?, Terra Nova, 10, 280-286, 1998.

Gerlach, T.M., Degassing of carbon dioxide from basaltic magma at spreading centers: II. Mid-ocean ridge basalts, J. Volcanol. Geotherm. Res., 39, 221-232, 1989.

Gerlach, T.M., Comment on "Mid-ocean ridge popping rocks; implications for degassing at ridge crests" by P. Sarda and D. Graham, Earth. Planet. Sci. Lett., 105, 566-567, 1991.

Gerlach, T.M., and E.J. Graeber, Volatile budget of Kilauea Volcano, Nature, 313, 273-277, 1985.

Gerlach, T.M.., K.A. McGee, T. Elias, A.J. Sutton, and M.P. Doukas, Carbon dioxide emission rate of Kilauea Volcano: implications for primary magma and the summit reservoir, J. Geophys. Res., 107, 2189, doi:10.1029/2001JB000407, 2002.

Gill, J., P. Torssander, H. LaPierre, R. Taylor, K. Kaiho, M. Koyama, M. Kusakabe, J. Aitchison, S. Cisowski, K. Dadey, K. Fujioka, A. Klaus, M. Lovell, K. Marsaglia, P. Pezard, B. Taylor, and K. Tazaki, Explosive deep water basalt in the Sumisu backarc rift, Science, 248, 1214-1217, 1990.

Goldstein, S.J., M.T. Murrell, D.R. Janecky, J.R. Delaney, and D.A. Clague, Geochronology and petrogenesis of MORB from the Juan de Fuca and Gorda ridges by ${ }^{238} \mathrm{U}-230 \mathrm{Th}$ disequilibrium, Earth Planet. Sci. lett., 109, 255-272, 1992.

Gregg, T.K.P., and J.H. Fink, Quantification of submarine lava flow morphology through analog experiments, Geology, 23, 73$76,1995$.

Graham, D., and P. Sarda, Reply to comment by T.M. Gerlach on "Mid-ocean ridge popping rocks: implications for degassing at ridge crests", Earth Planet. Sci. Lett., 105, 568-573, 1991.

Griffiths, R.W., and J.H. Fink, Solidification and morphology of submarine lavas: a dependence on extrusion rate, $J$. Geophys. Res., 97, 19729-19737, 1992.

Hauri, E., K. Gronvold, N. Oskarsson, and D. McKenzie, Abundance of carbon in the Icelandic mantle: constraints from melt inclusions, Trans. Am. Geophys. Union, EOS., 2002.

Head, J.W., and L. Wilson, Lava fountain heights at Pu'u O'o, 
Kilauea, Hawaii; Indicators of amount and variations of exsolved magmatic volatiles, J. Geophy. Res., 92, 13715-13719, 1987.

Head, J.W., and L. Wilson, Basaltic explosive eruptions: Influence of gas release patterns and volume fluxes on near-vent dynamic morphology, and the formation of subsequent pyroclastic deposits (cinder cones, spatter cones, rootless flows, lava ponds, and lava flows), J. Volcanol. Geotherm. Res., 37, 261-271, 1989.

Head, J.W., and L. Wilson, Deep submarine pyroclastic eruptions: Theory and predicted landforms and deposits, J. Volcanol. Geotherm. Res., 121, 155-193, 2003.

Hekinian, R., M. Chaigneau, and J.-L. Cheminee, Popping rocks and lava tubes from the Mid-Atlantic rift valley at $36^{\circ} \mathrm{N}$, Nature, 245, 277, 1973.

Hon, K., C.C. Heliker, and J.I. Kjargaard, Limu o Pele: a new kind of hydroclastic tephra from Kilauea Volcano, Hawaii, Geol. Soc. Am., 20, A112-A113, 1988.

Javoy, M., and F. Pineau, The volatiles record of a "popping" rock from the Mid-Atlantic Ridge at $14^{\circ} \mathrm{N}$ : chemical and isotopic compositions of gas trapped in the vesicles, Earth Planet. Sci. Lett., 107, 598-611, 1991.

Karlin, R.E., and R.A. Zierenberg, Sedimentation and neotectonism in the SESCA area, Escanaba Trough, U.S. Geol. Surv. Bull., 2022, 131-141, 1994.

Kelley, D.S., M.D. Lilley, J.E. Lupton, and E.J. Olson, Enriched $\mathrm{H}_{2}, \mathrm{CH}_{4}$, and ${ }^{3} \mathrm{He}$ concentrations in hydrothermal plumes associated with the 1996 Gorda Ridge eruptive event, Deep-Sea Res. II, 45, 2665-2682, 1998.

Lupton, J.E., A far-field hydrothermal plume from Loihi Seamount, Science, 272, 976-979, 1996.

Lupton, J.E., Hydrothermal helium plumes in the Pacific Ocean, $J$. Geophys. Res., 103, 15853-15868, 1998.

Lupton, J.E., E.T. Baker, R. Embley, R. Greene, and L. Evans, Anomalous helium and heat signatures associated with the 1998 Axial Volcano event, Juan de Fuca Ridge, Geophys. Res. Lett., 26, 3449-3452, 1999a.

Lupton, J.E., E.T. Baker, and G.J. Massoth, Helium, heat and the generation of hydrothermal event plumes at mid-ocean ridges, Earth Planet. Sci. Lett., 171, 343-350, 1999b.

Maicher, D., and J.D.L. White, The formation of deep-sea limu o Pele, Bull. Volcanol., 63, 482-496, 2001.

Mattey, D.P., R.H. Carr, I.P. Wright, and C.T. Pillinger, Carbon isotopes in submarine basalts, Earth Planet. Sci. Lett., 70, 196-206, 1984.

Mattox, T.N., and M. T. Mangan, Littoral hydrovolcanic explosions: a case study of lava-seawater interaction at Kilauea Volcano, J. Volcanol. Geotherm. Res., 75, 1-17, 1997.

MBARI Mapping Team, MBARI west coast seamounts and ridges multibeam survey, Monterey Bay Aquarium Research Institute Digital Data Series, No. 7, 2001.

McClain, J.S., J.A. Orcutt, and M. Burnett, The East Pacific Rise in cross-section: A seismic model, J. Geophys. Res. 90, 8627$8640,1985$.

Michael, P., Regionally distinctive sources of depleted MORB: Evidence from trace elements and $\mathrm{H}_{2} \mathrm{O}$, Earth Planet. Sci. Lett., 131, 301-320, 1995.
Moore, J.G., Vesicularity and $\mathrm{CO}_{2}$ in mid-ocean ridge basalt, Nature, 282, 250-253, 1979.

Morton, J.L., R.A. Zierenberg, and C.A. Reiss, Geologic, hydrothermal, and biologic studies at Escanaba Trough: an introduction, U.S. Geol. Surv. Bull., 2022, 1-18, 1994.

Normark, W.R., and F. Serra, Vertical tectonics in northern Escanaba Trough as recorded by thick late Quaternary turbidites, J. Geophys. Res., 106, 13,793-13,802, 2001.

Parfitt, E.A., and L. Wilson, Explosive volcanic eruptions-IX. The transition between Hawaiian-style fountaining and strombolian explosive activity, Geophys. J. Internat., 121, 226-232, 1995.

Peng, D.-Y. and D.B. Robinson, The calculation of three-phase solid-liquid-vapor equilibrium using an equation of state, Advances in Chemistry Series 182, American Chemical Society, Washington, D.C. 1979, 185-196, 1979.

Perfit, M.R., and W.W. Chadwick Jr., Magmatism at mid-ocean ridges: Constraints from volcanological and geochemical investigations, in Faulting and Magmatism at Mid-Ocean Ridges, Geophyical Monograph 106, Am. Geophys. Union, Washington D.C., 59-115, 1998.

Pineau, F., M. Javoy, and Y. Bottinga, ${ }^{13} \mathrm{C} /{ }^{12} \mathrm{C}$ ratios of rocks and inclusions in popping rocks of the Mid-Atlantic Ridge: their bearing on the problem of isotopic composition of deep seated carbon, Earth Planet. Sci. Lett., 29, 413-421, 1976.

Pineau, F., and M. Javoy, Carbon isotopes and concentrations in midocean ridge basalts, Earth Planet. Sci. Lett., 62, 239-257, 1983.

Ripepe, M., M. Rossi, and G. Saccorotti, Image processing of explosive activity at Stromboli, J. Volcanol. Geotherm. Res., 54, 335-351, 1993.

Rohr, K., B. Mildreit, and C.J. Yorath, Asymmetric deep crustal structure across the Juan de Fuca Ridge, Geology, 16, 533-537, 1988.

Ross, S.L., and R.A. Zierenberg, Volcanic geomorphology of the SESCA and NESCA sites, Escanaba trough, U.S. Geol. Surv. Bull., 2022, 143-151, 1994.

Rubin, K., Degassing of metals and metalloids from erupting seamount and mid-ocean ridge volcanoes: Observations and predictions, Geochim. Cosmochim. Acta, 61, 3525-3542, 1997.

Rubin, K.H., M.C. Smith, M.R. Perfit, D.M. Christie, and L.F. Sacks, Geochronology and geochemistry of lavas from the 1996 North Gorda Ridge eruption, Deep-Sea Res. II, 45, 2571-2597, 1998.

Saal, A.E., E.H. Hauri, C.H. Langmuir, and M.R. Perfit, Vapor undersaturation in primitive mid-ocean ridge basalt and the volatile content of the Earth's upper mantle, Nature 419, 451455,2002 ..

Sarda, P., and D. Graham, Mid-ocean ridge popping rocks: implications for degassing at ridge crests, Earth Planet. Sci. Lett., 97, 268-289, 1990.

Sinton, J.M., and R.S. Detrick, Mid-ocean ridge magma chambers, J. Geophys. Res., 97, 197-216, 1992.

Sparks, R.S.J.,The dynamics of bubble formation and growth in magmas: A review and analysis, J. Volcanol. Geotherm. Res., 3, 1-37, 1978.

Staudacher, T., P. Sarda, S.H. Richardson, J.C. Allegre, I. Sagna, and L.V. Dimitriev, Noble gases in basalt glasses from the Mid- 
Atlantic Ridge topographic high at $14^{\circ} \mathrm{N}$; geodynamic consequences, Earth Planet. Sci. Lett., 96, 119-133, 1989.

Stolper, E.M., and J.R. Holloway, Experimental determination of the solubility of carbon dioxide in molten basalt at low pressure, Earth Planet. Sci. Lett., 87, 397-408, 1988.

Vergniolle, S., and C. Jaupart, Separated two-phase flow and basaltic eruptions, J. Geophys. Res., 91, 12842-12860, 1986.

Vergniolle, S., and C. Jaupart, Dynamics of degassing at Kilauea Volcano, Hawaii, J. Geophys. Res., 95, 2793-2809, 1990.

Vergniolle, S. and M. Mangan, Hawaiian and strombolian eruptions, in Encyclopedia of Volcanoes, ed. by H. Sigurdsson, Academic Press, San Diego, 447-461, 2000.

Wilson, L., and J.W. Head, Ascent and eruption of basaltic magma on the Earth and Moon, J. Geophys. Res., 86, 2971-3001, 1981.
Zuffa, G.G., W.R. Normark, F. Serra, and C.A. Brunner, Turbidite megabeds in an oceanic rift valley recording Jokulhlaups of Late Pleistocene glacial lakes of the Western United States, $J$. Geol., 108, 253-274, 2000.

David A. Clague, Alicé S. Davis, Monterey Bay Aquarium Research Institute, 7700 Sandholdt Road, Moss Landing, CA 95039-9644

Jacqueline E. Dixon, Rosenstiel School of Marine and Atmospheric Science, University of Miami, 4400 Rickenbacker Causeway, Miami, FL 33149 